Article

\title{
The Masked Polar Group Incorporation (MPGI) Strategy in Drug Design: Effects of Nitrogen Substitutions on Combretastatin and Isocombretastatin Tubulin Inhibitors
}

\author{
Myriam González 1,2,3 , Younes Ellahioui 1,4 ${ }^{1, \text { Raquel Álvarez }}{ }^{1,2,3}$, Laura Gallego-Yerga ${ }^{1,2,3}$, \\ Esther Caballero ${ }^{1,2,3}$, Alba Vicente-Blázquez ${ }^{1,2,3,5}$, Laura Ramudo ${ }^{6}$, Miguel Marín Folgado 1,2,3, \\ Cristina Sanz ${ }^{1,2,3}$, Manuel Medarde ${ }^{1,2,3}$ and Rafael Pelaéz 1,2,3,*(D) \\ 1 Laboratorio de Química Orgánica y Farmacéutica, Departamento de Ciencias Farmacéuticas, \\ Universidad de Salamanca, Campus Miguel de Unamuno, E-37007 Salamanca, Spain; \\ mygondi@usal.es (M.G.); youn@usal.es (Y.E.); raquelalvarez@usal.es (R.Á.); gallego@usal.es (L.G.-Y.); \\ escab@usal.es (E.C.); avicenteblazquez@usal.es (A.V.-B.); id00681470@usal.es (M.M.F.); \\ cristina.scuesta@usal.es (C.S.); medarde@usal.es (M.M.) \\ 2 Instituto de Investigación Biomédica de Salamanca (IBSAL), Facultad de Farmacia, \\ Universidad de Salamanca, Campus Miguel de Unamuno, E-37007 Salamanca, Spain \\ 3 Centro de Investigación de Enfermedades Tropicales de la Universidad de Salamanca (CIETUS), \\ Facultad de Farmacia, Universidad de Salamanca, Campus Miguel de Unamuno, E-37007 Salamanca, Spain \\ 4 Departamento de Biología y Geología, Física y Química Inorgánica, ESCET, Universidad Rey Juan Carlos, \\ Calle Tulipán s/n, Móstoles, E-28933 Madrid, Spain \\ 5 Laboratory of Cell Death and Cancer Therapy, Department of Molecular Biomedicine, \\ Centro de Investigaciones Biológicas, Consejo Superior de Investigaciones Científicas (CSIC), \\ E-28040 Madrid, Spain \\ 6 Departamento de Fisiología y Farmacología, Universidad de Salamanca, Campus Miguel de Unamuno, \\ E-37007 Salamanca, Spain; ramudo@usal.es \\ * Correspondence: pelaez@usal.es; Tel.: +34-923-677554890
}

Academic Editor: Romano Silvestri

Received: 15 October 2019; Accepted: 21 November 2019; Published: 26 November 2019

\begin{abstract}
Colchicine site ligands suffer from low aqueous solubility due to the highly hydrophobic nature of the binding site. A new strategy for increasing molecular polarity without exposing polar groups-termed masked polar group incorporation (MPGI) — was devised and applied to nitrogenated combretastatin analogues. Bulky ortho substituents to the pyridine nitrogen hinder it from the hydrophobic pocket while increasing molecular polarity. The resulting analogues show improved aqueous solubilities and highly potent antiproliferative activity against several cancer cell lines of different origin. The more potent compounds showed moderate tubulin polymerization inhibitory activity, arrested the cell cycle of treated cells at the $\mathrm{G}_{2} / \mathrm{M}$ phase, and subsequently caused apoptotic cell death represented by the cells gathered at the subG $G_{0} / \mathrm{G}_{1}$ population after $48 \mathrm{~h}$ of treatment. Annexin V/Propidium Iodide (PI) double-positive cells observed after $72 \mathrm{~h}$ confirmed the induction of apoptosis. Docking studies suggest binding at the colchicine site of tubulin in a similar way as combretastatin A4, with the polar groups masked by the vicinal substituents. These results validate the proposed strategy for the design of colchicine site ligands and open a new road to increasing the aqueous solubility of ligands binding in apolar environments.
\end{abstract}

Keywords: tubulin; colchicine-site; combretastatins; isocombretastatins; phenstatins; nitrogenated; masked polar group introduction; solubility; cytotoxicity; docking 


\section{Introduction}

The microtubule filament system of eukaryotic cells is an important drug target for pesticides, antiparasitic and anticancer agents [1]. Cell microtubules show complex and highly regulated dynamic behavior essential for their functioning in cell shape maintenance, intracellular trafficking, cell motility and migration, and the formation of the mitotic spindle during cell division. The microtubule targeting agents (MTAs) bind to the main constituent of the microtubules, the $\alpha \beta$-tubulin dimers, in several different domains and alter their polymerization-depolymerization equilibria. They are often referred to as antimitotics, as their most patent effect is interference with the highly dynamic mitotic spindle, and depending on the effect they show on microtubule mass, they are often classified as microtubule stabilizing (MSA) or microtubule destabilizing agents (MDA). [2] The recent discovery that some types of MTAs, such as the colchicine-site binding drugs combretastatins, can shut down tumor neovasculature and behave as vascular disrupting agents (VDAs) has fostered an even greater interest in this class of drugs [3].

Combretastatin A4 (Figure 1) is the most prominent member of a family of natural product-derived MDAs, which is in clinical trials as a VDA [4]. Combretastatin A4 suffers from low water solubility, which has been circumvented by means of phosphate prodrug, and from isomerization of the $Z$ stilbene to the less potent $E$ isomer. Therefore, many combretastatin A4 modifications have been explored in order to provide new drugs with improved therapeutic profiles. The replacement of the olefinic bridge by small heterocycles [5] and its transformation into nonisomerizable one-atom bridges, such as the isocombretastatins [6,7], the phenstatins [8] and other derivatives have been amongst the most successful strategies aimed at increasing the configurational stability of combretastatins. The hydroxyl group used to anchor the phosphate in prodrug formation has recently been shown to represent an additional liability, as it suffers drug metabolism, which results in drug resistance [9]. Attempts to find alternatives to the 3-hydroxy-4-methoxyphenyl ring (B-ring) of combretastatin A4 have resulted in highly potent derivatives, such as indole [10-13] or naphthalene [13] analogues but with reduced water solubilities.

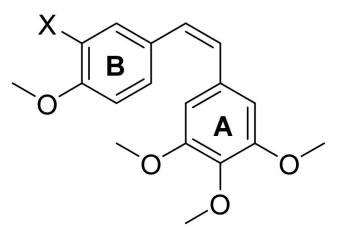

$\underline{\mathrm{X}}$ $\mathrm{OPO}_{3} \mathrm{Na}_{2}$ Combretastatin A4 phosphate (CA4P)

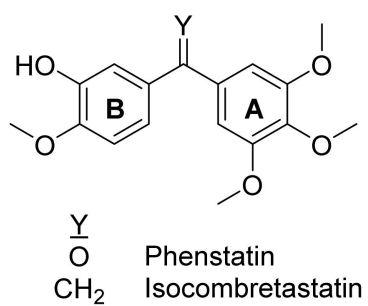

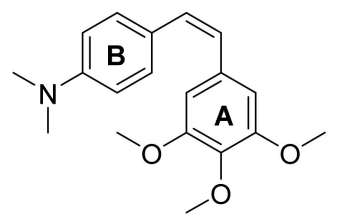

Dimethylaminocombretastatin

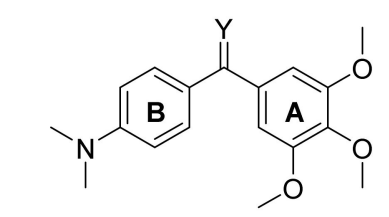

$\frac{Y}{\mathrm{O}}$ Dimethylaminophenstatin $\mathrm{CH}_{2}$ Dimethylaminoisocombretastatin
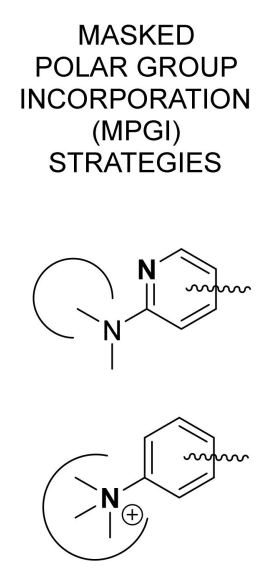

Figure 1. Structures of representative colchicine-site ligands and a summary of the masked polar group incorporation strategy followed in this work.

A dimethylaminophenyl ring can be thought of as an open analogue of an indole ring, and has been shown as an acceptable replacement for the B-ring of combretastatin A4 [14,15], but we have shown that it is not amenable to additional substitutions for solubility enhancement [16]. A frequent strategy applied to improve the solubility of drugs is the incorporation of polar groups, and to mask them as intramolecular hydrogen bonds [17]. However, this strategy can be difficult if the polar groups are placed in hydrophobic regions of the target, as it is the case with the colchicine site. Here, we propose 
a novel alternative strategy called masked polar group incorporation (MPGI), which implies the introduction of polar groups with vicinal bulky substituents in order to mask them from the outside, thus allowing binding at low polar binding sites while increasing the intrinsic water solubility. To this end, we have introduced nitrogen atoms on phenyl rings to form pyridines within the context of dimethylamino combretastatin and isocombretastatin analogues (Figure 1). A related strategy is the formation of ammonium salts with a polar core surrounded by hydrophobic alkyl groups. We have shown here that this new strategy is successful in achieving colchicine site ligands with improved intrinsic solubility profiles, while maintaining high antimitotic potency and in vitro activity associated with the inhibition of tubulin polymerization by binding at the colchicine site of tubulin, thus providing a proof of concept. These results guarantee further studies on these compounds, and provide a new strategy for the design of new colchicine site ligands with improved properties.

\section{Results}

\subsection{Chemistry}

\subsubsection{Chemical Synthesis}

The phenstatin derivatives were prepared by two different methodologies. On one hand, compounds $\mathbf{1 a}, \mathbf{1 b}, \mathbf{1 f}$, and $\mathbf{1 g}$ were obtained by one-step reactions between aromatic organolithium derivatives and sodium 3,4,5-trimethoxybenzoate. The starting organometallic compounds were synthesized by reaction between the bromo derivative (A, B, F or $\mathbf{G})$ and $n$-butyllithium ( $n \mathrm{BuLi})$, whereas the sodium benzoate salt was prepared by treating 3,4,5-trimethoxybenzoic acid with sodium hydride. On the other hand, phenstatins $\mathbf{1 c}, \mathbf{1 d}, \mathbf{1 e}$ and $\mathbf{1 h}$ were alternatively prepared using a two-step synthesis. First, the organolithium compounds obtained from methoxybenzene derivatives $\mathbf{C}^{\prime}, \mathbf{D}^{\prime}$, or $\mathbf{E}^{\prime}$, afforded the intermediate alcohols by nucleophilic addition to aldehydes $\mathbf{C}, \mathbf{D}$ or $\mathbf{H}$. In a second step, oxidation of the diarylmethanol derivatives with pyridinium dichromate (PDC) gave the required diarylketones (1c, 1d, 1e and $\mathbf{1 h}$ ).

In order to increase the solubility of the compounds, ketone groups were replaced by oximes treating the phenstatins $\mathbf{1 a}-\mathbf{1 h}$ with hydroxylamine hydrochloride and pyridine as catalyst in refluxing methanol to give $\mathbf{2 a - 2 h}$. In these reactions, a 1:1 Z/E isomer mixture that, in some cases, could be separated by column chromatography or by crystallization was obtained.

A second bridge modification was attempted by converting phenstatins $\mathbf{1 a}-\mathbf{1 h}$ into isocombretastatins 3a-3h through a Wittig reaction. The diarylketones were treated with triphenylphosphonium methylide, synthesized by reaction between methyltriphenylphosphonium iodide and $n$-butyllithium in dry tetrahydrofuran (THF).

To explore the effect of the double bond at the bridge of the diaryl compounds, the ethenylidene group was converted into ethyl group by reduction of isocombretastatins $\mathbf{3 d}, \mathbf{3 e}$, and $\mathbf{3 f}$ under hydrogen atmosphere using $\mathrm{Pd} / \mathrm{C}$ as catalyst to get $4 \mathrm{~d}, 4 \mathrm{e}$, and $4 \mathrm{f}$.

The importance of the double bond arrangement in these systems was assessed by comparing the properties of the synthesized isocombretastatins with their isomeric combretastatins analogues. They were accessed via Wittig reaction by the nucleophilic addition of triphenyl(3,4,5-trimethoxybenzyl)phosphonium iodide to the aldehydes $\mathbf{A}^{\prime \prime}-\mathbf{I}^{\prime \prime}$ to obtain combretastatins $\mathbf{8} \mathbf{a}-\mathbf{8 i}$.

Finally, another strategy to increase the water solubility of the synthesized compounds involved the preparation of quaternary ammonium salts for some of the derivatives having dialkylamino groups at the $\mathrm{B}$ ring. For that purpose, phenstatins $\mathbf{1 a}, \mathbf{1 d}$, and 1e; oxime $\mathbf{2} \mathbf{a}$; isocombretastatins $\mathbf{3 a}$ and $\mathbf{3 d}$; and combretastatins $\mathbf{8 a}, \mathbf{8 b}$, and $\mathbf{8 i}$ were treated with iodomethane in refluxing acetone to obtain the corresponding ammonium iodide derivatives.

The whole synthetic approach, which is detailed in Scheme 1, succeeded in obtaining a set of 41 diaryl compounds with several methoxy patterns at $\mathrm{A}$ ring, different nitrogen functional groups at $\mathrm{B}$ ring and modifications at the bridge to establish structure-activity relationship studies. 


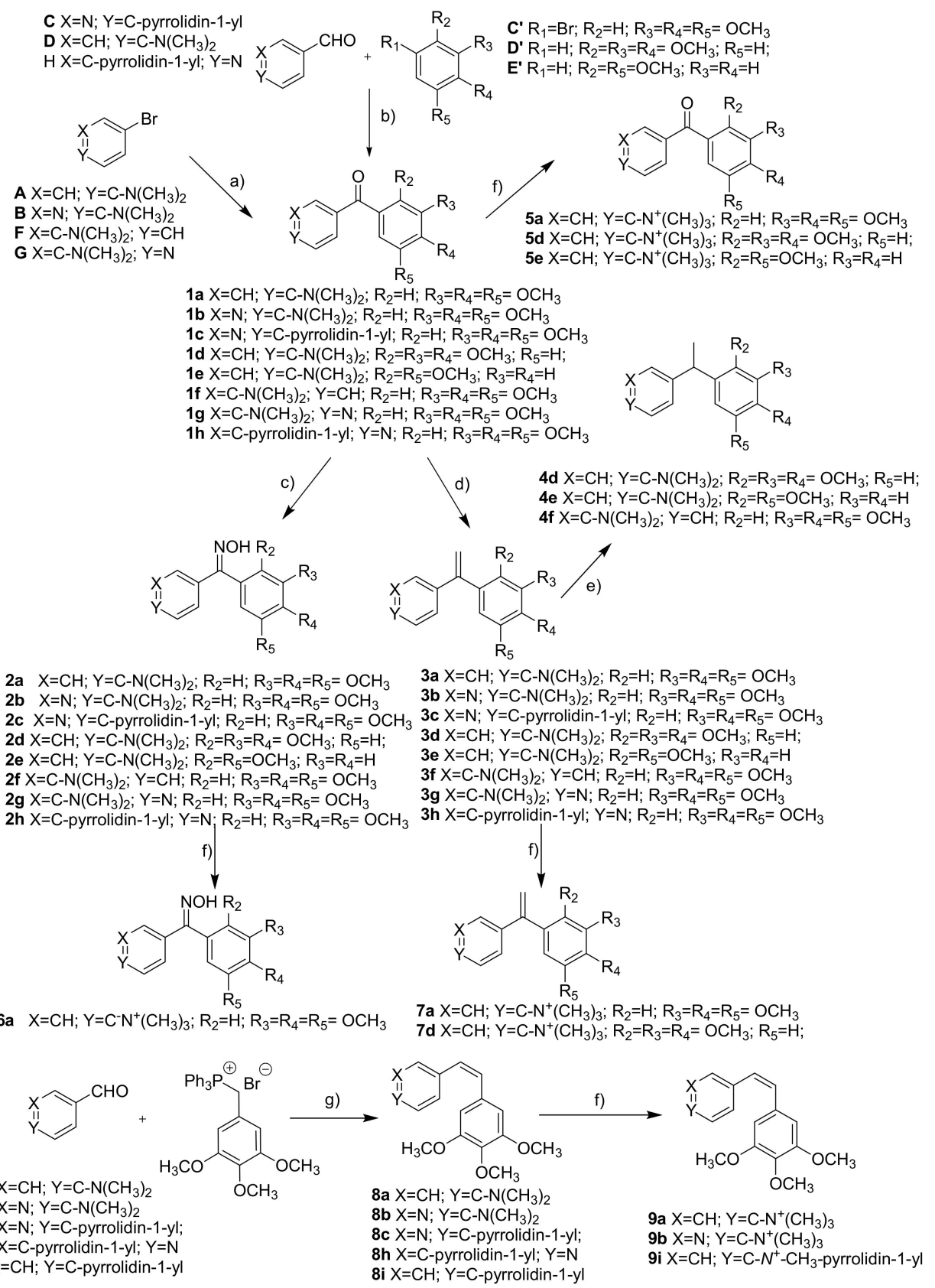

Scheme 1. Synthesis of compounds 1a-9i. (a) 1. $n \mathrm{BuLi}, \mathrm{THF},-78{ }^{\circ} \mathrm{C} ; 2.3,4,5$-trimethoxybenzoic acid, $\mathrm{NaH}, 0{ }^{\circ} \mathrm{C}-\mathrm{rt}$; (b) 1. $n \mathrm{BuLi}, \mathrm{THF},-78{ }^{\circ} \mathrm{C}$; 2 . ArCHO, THF; 3. PDC, $\mathrm{HSO}_{4} \mathrm{Bu}_{4} \mathrm{~N}$; (c) $\mathrm{NH}_{2} \mathrm{OH} \cdot \mathrm{HCl}$, pyridine, $\mathrm{MeOH}$, reflux; (d) $\mathrm{Ph}_{3} \mathrm{PMeI}, n \mathrm{BuLi}, \mathrm{THF},-40{ }^{\circ} \mathrm{C}$; (e) $\mathrm{H}_{2}, \mathrm{Pd} / \mathrm{C}, \mathrm{EtOH}, \mathrm{rt}$; (f) MeI, acetone, reflux; (g) $n \mathrm{BuLi}, \mathrm{THF},-78{ }^{\circ} \mathrm{C}$.

\subsubsection{Solubility}

One of the expected effects of introducing nitrogen substitutions on combretastatin and isocombretastatin analogues, is an increase in aqueous solubility. Solubility was spectrophotometrically determined in phosphate buffer at $\mathrm{pH}$ 7. UV absorbance of soluble compounds was measured after shaking and microfiltration. Values are displayed in Table 1, showing a significant improvement of aqueous solubility in comparison to CA-4 (1 $\mu \mathrm{g} / \mathrm{mL})$ : 10- to 150-fold in compounds with dimethylaminophenyl moieties, and 10- to 583-fold in compounds with a pyridine moiety. In addition, aqueous solubilities of the corresponding ammonium salts are over $1 \mathrm{mg} / \mathrm{mL}$. 
Table 1. IC 50 values for cell proliferation, solubility and Tubulin polymerization inhibitory (TPI) activity for the synthesized compounds.

\begin{tabular}{|c|c|c|c|c|c|c|c|c|c|c|c|c|c|}
\hline \multirow[t]{3}{*}{ Compound } & \multirow{3}{*}{$\mathrm{z}$} & & & & & & & \multirow[t]{3}{*}{$\begin{array}{c}\text { Solub. } \\
(\mu \mathrm{g} / \mathrm{mL})\end{array}$} & \multirow[t]{3}{*}{$\begin{array}{l}\text { HeLa IC } \\
\text { (nM) }\end{array}$} & \multirow[t]{3}{*}{$\begin{array}{l}\text { HT-29 IC } 50 \\
\text { (nM) }\end{array}$} & \multirow{3}{*}{$\begin{array}{c}\text { HT-29 } \text { IC }_{50}(\mathrm{nM}) \\
\text { Verap } 10 \mu \mathrm{M}\end{array}$} & \multirow{3}{*}{$\begin{array}{c}\text { MCF7 IC IC } \\
\text { (nM) }\end{array}$} & \multirow{3}{*}{$\begin{array}{l}\text { TPI IC }_{50} \\
(\mu \mathrm{M})\end{array}$} \\
\hline & & \multicolumn{2}{|c|}{$\mathrm{Ar}_{1}$} & \multicolumn{4}{|c|}{$\mathrm{Ar}_{2}$} & & & & & & \\
\hline & & $x$ & $\mathrm{Y}$ & $\mathbf{R}_{2}$ & $\mathbf{R}_{3}$ & $\mathbf{R}_{4}$ & $\mathbf{R}_{5}$ & & & & & & \\
\hline $1 \mathrm{a}$ & \multirow{8}{*}{$\mathrm{O}$} & $\mathrm{CH}$ & $\mathrm{C}-\mathrm{N}-\left(\mathrm{CH}_{3}\right)_{2}$ & $\mathrm{H}$ & $\mathrm{OCH}_{3}$ & $\mathrm{OCH}_{3}$ & $\mathrm{OCH}_{3}$ & 48 & 90 & 400 & & & $>20$ \\
\hline $1 b$ & & $\mathrm{~N}$ & $\mathrm{C}-\mathrm{N}-\left(\mathrm{CH}_{3}\right)_{2}$ & $\mathrm{H}$ & $\mathrm{OCH}_{3}$ & $\mathrm{OCH}_{3}$ & $\mathrm{OCH}_{3}$ & 10.5 & $>1000$ & $>1000$ & $>1000$ & $>1000$ & $>20$ \\
\hline $1 \mathrm{c}$ & & $\mathrm{N}$ & C-N- $\left(\mathrm{CH}_{2}\right)_{4}$ & $\mathrm{H}$ & $\mathrm{OCH}_{3}$ & $\mathrm{OCH}_{3}$ & $\mathrm{OCH}_{3}$ & - & 1600 & 5170 & 4000 & 2330 & $>20$ \\
\hline $1 \mathrm{~d}$ & & $\mathrm{CH}$ & $\mathrm{C}-\mathrm{N}-\left(\mathrm{CH}_{3}\right)_{2}$ & $\mathrm{OCH}_{3}$ & $\mathrm{OCH}_{3}$ & $\mathrm{OCH}_{3}$ & $\mathrm{H}$ & - & 413 & 500 & 650 & 407 & $>20$ \\
\hline $1 \mathrm{e}$ & & $\mathrm{CH}$ & $\mathrm{C}-\mathrm{N}-\left(\mathrm{CH}_{3}\right)_{2}$ & $\mathrm{OCH}_{3}$ & $\mathrm{H}$ & $\mathrm{H}$ & $\mathrm{OCH}_{3}$ & - & $>1000$ & $>1000$ & $>1000$ & $>1000$ & $>20$ \\
\hline If & & $\mathrm{C}-\mathrm{N}-\left(\mathrm{CH}_{3}\right)_{2}$ & $\mathrm{CH}$ & $\mathrm{H}$ & $\mathrm{OCH}_{3}$ & $\mathrm{OCH}_{3}$ & $\mathrm{OCH}_{3}$ & 11 & 180 & 460 & 283 & 320 & $>20$ \\
\hline $1 \mathrm{~g}$ & & $\mathrm{C}-\mathrm{N}-\left(\mathrm{CH}_{3}\right)_{2}$ & $\mathrm{~N}$ & $\mathrm{H}$ & $\mathrm{OCH}_{3}$ & $\mathrm{OCH}_{3}$ & $\mathrm{OCH}_{3}$ & 33.8 & 387 & 313 & 377 & 223 & $>20$ \\
\hline $1 \mathrm{~h}$ & & $\mathrm{C}-\mathrm{N}-\left(\mathrm{CH}_{2}\right)_{4}$ & $\mathrm{~N}$ & $\mathrm{H}$ & $\mathrm{OCH}_{3}$ & $\mathrm{OCH}_{3}$ & $\mathrm{OCH}_{3}$ & 20 & 18 & 71 & 63 & 17 & 9.1 \\
\hline $2 a$ & \multirow{7}{*}{$\mathrm{NHOH}$} & $\mathrm{CH}$ & $\mathrm{C}-\mathrm{N}-\left(\mathrm{CH}_{3}\right)_{2}$ & $\mathrm{H}$ & $\mathrm{OCH}_{3}$ & $\mathrm{OCH}_{3}$ & $\mathrm{OCH}_{3}$ & 74 & 800 & 1000 & & & $>20$ \\
\hline $2 c$ & & $\mathrm{~N}$ & $\mathrm{C}-\mathrm{N}-\left(\mathrm{CH}_{2}\right)_{4}$ & $\mathrm{H}$ & $\mathrm{OCH}_{3}$ & $\mathrm{OCH}_{3}$ & $\mathrm{OCH}_{3}$ & - & $>1000$ & $>1000$ & $>1000$ & $>1000$ & $>20$ \\
\hline $2 \mathrm{~d}$ & & $\mathrm{CH}$ & $\mathrm{C}-\mathrm{N}-\left(\mathrm{CH}_{3}\right)_{2}$ & $\mathrm{OCH}_{3}$ & $\mathrm{OCH}_{3}$ & $\mathrm{OCH}_{3}$ & $\mathrm{H}$ & - & 373 & 320 & 667 & 277 & $>20$ \\
\hline $2 e$ & & $\mathrm{CH}$ & C-N- $\left(\mathrm{CH}_{3}\right)_{2}$ & $\mathrm{OCH}_{3}$ & $\mathrm{H}$ & $\mathrm{H}$ & $\mathrm{OCH}_{3}$ & - & $>1000$ & $>1000$ & $>1000$ & $>1000$ & $>20$ \\
\hline $2 f$ & & $\mathrm{C}-\mathrm{N}-\left(\mathrm{CH}_{3}\right)_{2}$ & $\mathrm{CH}$ & $\mathrm{H}$ & $\mathrm{OCH}_{3}$ & $\mathrm{OCH}_{3}$ & $\mathrm{OCH}_{3}$ & 153 & $>1000$ & $>1000$ & $>1000$ & $>1000$ & $>20$ \\
\hline $2 \mathrm{~g}$ & & $\mathrm{C}-\mathrm{N}-\left(\mathrm{CH}_{3}\right)_{2}$ & $\mathrm{~N}$ & $\mathrm{H}$ & $\mathrm{OCH}_{3}$ & $\mathrm{OCH}_{3}$ & $\mathrm{OCH}_{3}$ & 583 & 533 & 3370 & 967 & 407 & $>20$ \\
\hline $2 \mathrm{~h}$ & & $\mathrm{C}-\mathrm{N}-\left(\mathrm{CH}_{2}\right)_{4}$ & $\mathrm{~N}$ & $\mathrm{H}$ & $\mathrm{OCH}_{3}$ & $\mathrm{OCH}_{3}$ & $\mathrm{OCH}_{3}$ & & & & & & \\
\hline $3 a$ & \multirow{8}{*}{$\mathrm{CH}_{2}$} & $\mathrm{CH}$ & $\mathrm{C}-\mathrm{N}-\left(\mathrm{CH}_{3}\right)_{2}$ & $\mathrm{H}$ & $\mathrm{OCH}_{3}$ & $\mathrm{OCH}_{3}$ & $\mathrm{OCH}_{3}$ & 30 & 40 & 70 & & & 1.9 \\
\hline $3 b$ & & $\mathrm{~N}$ & $\mathrm{C}-\mathrm{N}-\left(\mathrm{CH}_{3}\right)_{2}$ & $\mathrm{H}$ & $\mathrm{OCH}_{3}$ & $\mathrm{OCH}_{3}$ & $\mathrm{OCH}_{3}$ & 13.5 & 150 & 277 & 100 & 81 & 35.9 \\
\hline $3 c$ & & $\mathrm{~N}$ & C-N- $\left(\mathrm{CH}_{2}\right)_{4}$ & $\mathrm{H}$ & $\mathrm{OCH}_{3}$ & $\mathrm{OCH}_{3}$ & $\mathrm{OCH}_{3}$ & - & 523 & 383 & 140 & - & $>20$ \\
\hline $3 d$ & & $\mathrm{CH}$ & $\mathrm{C}-\mathrm{N}-\left(\mathrm{CH}_{3}\right)_{2}$ & $\mathrm{OCH}_{3}$ & $\mathrm{OCH}_{3}$ & $\mathrm{OCH}_{3}$ & $\mathrm{H}$ & - & 1000 & 4000 & 1500 & 2000 & $>20$ \\
\hline $3 e$ & & $\mathrm{CH}$ & $\mathrm{C}-\mathrm{N}-\left(\mathrm{CH}_{3}\right)_{2}$ & $\mathrm{OCH}_{3}$ & $\mathrm{H}$ & $\mathrm{H}$ & $\mathrm{OCH}_{3}$ & - & $>1000$ & $>1000$ & $>1000$ & $>1000$ & $>20$ \\
\hline $3 f$ & & $\mathrm{C}-\mathrm{N}-\left(\mathrm{CH}_{3}\right)_{2}$ & $\mathrm{CH}$ & $\mathrm{H}$ & $\mathrm{OCH}_{3}$ & $\mathrm{OCH}_{3}$ & $\mathrm{OCH}_{3}$ & 21 & $>1000$ & $>1000$ & $>1000$ & $>1000$ & $>20$ \\
\hline $3 g$ & & $\mathrm{C}-\mathrm{N}-\left(\mathrm{CH}_{3}\right)_{2}$ & $\mathrm{~N}$ & $\mathrm{H}$ & $\mathrm{OCH}_{3}$ & $\mathrm{OCH}_{3}$ & $\mathrm{OCH}_{3}$ & 136 & 403 & 397 & 380 & 367 & $>20$ \\
\hline $3 \mathrm{~h}$ & & $\mathrm{C}-\mathrm{N}-\left(\mathrm{CH}_{2}\right)_{4}$ & $\mathrm{~N}$ & $\mathrm{H}$ & $\mathrm{OCH}_{3}$ & $\mathrm{OCH}_{3}$ & $\mathrm{OCH}_{3}$ & 62 & 257 & 477 & 230 & 317 & $>20$ \\
\hline $4 d$ & \multirow{3}{*}{$\mathrm{CH}_{3}$} & $\mathrm{CH}$ & $\mathrm{C}-\mathrm{N}-\left(\mathrm{CH}_{3}\right)_{2}$ & $\mathrm{OCH}_{3}$ & $\mathrm{OCH}_{3}$ & $\mathrm{OCH}_{3}$ & $\mathrm{H}$ & - & $>1000$ & $>1000$ & $>1000$ & $>1000$ & $>20$ \\
\hline $4 e$ & & $\mathrm{CH}$ & $\mathrm{C}-\mathrm{N}-\left(\mathrm{CH}_{3}\right)_{2}$ & $\mathrm{OCH}_{3}$ & $\mathrm{H}$ & $\mathrm{H}$ & $\mathrm{OCH}_{3}$ & - & $>1000$ & $>1000$ & $>1000$ & $>1000$ & $>20$ \\
\hline $4 \mathrm{f}$ & & $\mathrm{C}-\mathrm{N}-\left(\mathrm{CH}_{3}\right)_{2}$ & $\mathrm{CH}$ & $\mathrm{H}$ & $\mathrm{OCH}_{3}$ & $\mathrm{OCH}_{3}$ & $\mathrm{OCH}_{3}$ & - & $>1000$ & $>1000$ & $>1000$ & $>1000$ & $>20$ \\
\hline $5 a$ & \multirow{3}{*}{$\mathrm{O}$} & $\mathrm{CH}$ & C-N $-\mathrm{N}^{+}\left(\mathrm{CH}_{3}\right)_{3}$ & $\mathrm{H}$ & $\mathrm{OCH}_{3}$ & $\mathrm{OCH}_{3}$ & $\mathrm{OCH}_{3}$ & - & $>1000$ & $>1000$ & $>1000$ & $>1000$ & $>20$ \\
\hline $5 d$ & & $\mathrm{CH}$ & C-N $-\mathrm{N}^{+}\left(\mathrm{CH}_{3}\right)_{3}$ & $\mathrm{OCH}_{3}$ & $\mathrm{OCH}_{3}$ & $\mathrm{OCH}_{3}$ & $\mathrm{H}$ & 4400 & $>1000$ & $>1000$ & $>1000$ & $>1000$ & $>20$ \\
\hline $5 e$ & & $\mathrm{CH}$ & C-N $-\mathrm{N}^{+}\left(\mathrm{CH}_{3}\right)_{3}$ & $\mathrm{OCH}_{3}$ & $\mathrm{H}$ & $\mathrm{H}$ & $\mathrm{OCH}_{3}$ & $>5000$ & $>1000$ & $>1000$ & $>1000$ & $>1000$ & $>20$ \\
\hline $6 a$ & $\mathrm{NHOH}$ & $\mathrm{CH}$ & $\mathrm{C}-\mathrm{N}^{+}-\left(\mathrm{CH}_{3}\right)_{3}$ & $\mathrm{H}$ & $\mathrm{OCH}_{3}$ & $\mathrm{OCH}_{3}$ & $\mathrm{OCH}_{3}$ & 1500 & $>1000$ & $>1000$ & $>1000$ & $>1000$ & $>20$ \\
\hline $7 a$ & \multirow{2}{*}{$\mathrm{CH}_{2}$} & $\mathrm{CH}$ & C-N $\mathrm{N}^{+}-\left(\mathrm{CH}_{3}\right)_{3}$ & $\mathrm{H}$ & $\mathrm{OCH}_{3}$ & $\mathrm{OCH}_{3}$ & $\mathrm{OCH}_{3}$ & 2500 & $>1000$ & $>1000$ & $>1000$ & $>1000$ & $>20$ \\
\hline $7 d$ & & $\mathrm{CH}$ & $\mathrm{C}^{-\mathrm{N}^{+}}-\left(\mathrm{CH}_{3}\right)_{3}$ & $\mathrm{OCH}_{3}$ & $\mathrm{OCH}_{3}$ & $\mathrm{OCH}_{3}$ & $\mathrm{H}$ & 1000 & $>1000$ & $>1000$ & $>1000$ & $>1000$ & $>20$ \\
\hline
\end{tabular}


Table 1. Cont.

\begin{tabular}{|c|c|c|c|c|c|c|c|c|c|c|c|c|}
\hline \multirow[t]{3}{*}{ Compound } & \multicolumn{6}{|c|}{$\begin{array}{ll}R_{5}^{\prime} & R_{4}\end{array}$} & \multirow[t]{3}{*}{$\begin{array}{c}\text { Solub. } \\
(\mu \mathrm{g} / \mathrm{mL})\end{array}$} & \multirow[t]{3}{*}{$\begin{array}{l}\text { HeLa IC }_{50} \\
\text { (nM) }\end{array}$} & \multirow[t]{3}{*}{$\begin{array}{l}\text { HT-29 IC } 50 \\
\text { (nM) }\end{array}$} & \multirow[t]{3}{*}{$\begin{array}{c}\text { HT-29 } \text { IC }_{50}(\mathrm{nM}) \\
\text { Verap } 10 \mu \mathrm{M}\end{array}$} & \multirow[t]{3}{*}{$\begin{array}{c}\text { MCF7 IC } \\
\text { (nM) }\end{array}$} & \multirow[t]{3}{*}{$\begin{array}{l}\text { TPI IC }_{50} \\
(\mu \mathrm{M})\end{array}$} \\
\hline & \multicolumn{2}{|c|}{$\mathrm{Ar}_{1}$} & & \multicolumn{2}{|c|}{$\mathrm{Ar}_{2}$} & & & & & & & \\
\hline & $x$ & $\mathrm{Y}$ & $\mathbf{R}_{2}$ & $\mathbf{R}_{3}$ & $\mathbf{R}_{4}$ & $\mathbf{R}_{5}$ & & & & & & \\
\hline $8 a$ & $\mathrm{CH}$ & $\mathrm{C}-\mathrm{N}-\left(\mathrm{CH}_{3}\right)_{2}$ & $\mathrm{H}$ & $\mathrm{OCH}_{3}$ & $\mathrm{OCH}_{3}$ & $\mathrm{OCH}_{3}$ & - & 208 & 503 & 102 & 273 & 3.4 \\
\hline $8 \mathbf{b}$ & $\mathrm{N}$ & $\mathrm{C}-\mathrm{N}-\left(\mathrm{CH}_{3}\right)_{2}$ & $\mathrm{H}$ & $\mathrm{OCH}_{3}$ & $\mathrm{OCH}_{3}$ & $\mathrm{OCH}_{3}$ & 44 & 57 & 78 & 50 & 63 & 5.1 \\
\hline $8 c$ & $\mathrm{~N}$ & $\mathrm{C}-\mathrm{N}-\left(\mathrm{CH}_{2}\right)_{4}$ & $\mathrm{H}$ & $\mathrm{OCH}_{3}$ & $\mathrm{OCH}_{3}$ & $\mathrm{OCH}_{3}$ & - & $>1000$ & $>1000$ & $>1000$ & $>1000$ & $>20$ \\
\hline $8 \mathrm{~h}$ & $\mathrm{C}-\mathrm{N}-\left(\mathrm{CH}_{2}\right)_{4}$ & $\mathrm{~N}$ & $\mathrm{H}$ & $\mathrm{OCH}_{3}$ & $\mathrm{OCH}_{3}$ & $\mathrm{OCH}_{3}$ & 65 & $>1000$ & $>1000$ & $>1000$ & $>1000$ & $>20$ \\
\hline $8 \mathrm{i}$ & $\mathrm{CH}$ & $\mathrm{C}-\mathrm{N}-\left(\mathrm{CH}_{2}\right)_{4}$ & $\mathrm{H}$ & $\mathrm{OCH}_{3}$ & $\mathrm{OCH}_{3}$ & $\mathrm{OCH}_{3}$ & - & 243 & 430 & 73 & 140 & - \\
\hline $9 a$ & $\mathrm{CH}$ & $\mathrm{C}-\mathrm{N}^{+}-\left(\mathrm{CH}_{3}\right)_{3}$ & $\mathrm{H}$ & $\mathrm{OCH}_{3}$ & $\mathrm{OCH}_{3}$ & $\mathrm{OCH}_{3}$ & - & $>1000$ & $>1000$ & $>1000$ & $>1000$ & $>20$ \\
\hline $9 b$ & $\mathrm{~N}$ & $\mathrm{C}-\mathrm{N}^{+}-\left(\mathrm{CH}_{3}\right)_{3}$ & $\mathrm{H}$ & $\mathrm{OCH}_{3}$ & $\mathrm{OCH}_{3}$ & $\mathrm{OCH}_{3}$ & 679 & $>1000$ & $>1000$ & $>1000$ & $>1000$ & $>20$ \\
\hline $9 \mathrm{i}$ & $\mathrm{CH}$ & $\mathrm{C}-\mathrm{N}^{+}-\left(\mathrm{CH}_{3}\right)-\left(\mathrm{CH}_{2}\right)_{4}$ & $\mathrm{H}$ & $\mathrm{OCH}_{3}$ & $\mathrm{OCH}_{3}$ & $\mathrm{OCH}_{3}$ & - & $>1000$ & $>1000$ & $>1000$ & $>1000$ & - \\
\hline
\end{tabular}




\subsection{Biology}

\subsubsection{Cell Viability}

The in vitro antiproliferative activity of the synthesized compounds was evaluated by a colorimetric reaction, using the MTT reagent. They were tested against three different human tumor cell lines: HeLa cervix epithelioid carcinoma, HT-29 colon adenocarcinoma, and MCF-7 breast adenocarcinoma. The compounds were initially tested at $1 \mu \mathrm{M}$, and for those inhibiting cell proliferation at least by a $50 \%$, the half maximal inhibitory concentration $\left(\mathrm{IC}_{50}\right)$ values were calculated. $p$-Dimethylaminophenyl derivatives 1a, 2a, 3a and 8a were used for comparison between phenyl and pyridine analogues. Moving the alkylamino substituent from a para to a meta position with respect to the bridge results in potency reduction, except for the phenstatin analogue 1f. However, the introduction of a nitrogen atom to form 2-dimethylaminopyridine derivatives entails a loss of activity, both for phenstatin analogues $(\mathbf{1} \mathbf{b}, \mathbf{2 b})$, while for isocombretastatins, it only involves a 2-3 times potency decrease (3b). For combretastatins, it implies an improvement in the cytotoxicity values down to tenths of nanomolar (8b). 2-Pyrrolidin-1-yl pyridine moieties resulted in highly potent antiproliferative phenstatins (i.e., compound $1 \mathrm{~h}$ ). On the other hand, the best 2-dimethylaminopyridine was combretastatin $\mathbf{8 b}$. All ammonium salts derivatives were not cytotoxic at micromolar concentrations.

In order to test whether these compounds are substrates of multi-drug resistance (MDR) glycoproteins, we have adopted a pharmacological approach and measured the $\mathrm{IC}_{50}$ values against HT-29 in the presence of $10 \mu \mathrm{M}$ verapamil, a known nonselective P-gP1/MDR1 inhibitor. As observed in Table 1 , there are no significant changes in the $\mathrm{IC}_{50}$ values for most compounds, except for combretastatins $\mathbf{8 a}$ and $\mathbf{8 i}$.

\subsubsection{Tubulin Polymerization Inhibition}

The effects of cytotoxic compounds on in vitro tubulin assembly were studied at $20 \mu \mathrm{M}$ concentration, and the $\mathrm{IC}_{50}$ values were determined for the more potent ones $(\mathbf{1} \mathbf{h}, \mathbf{3 b}$ and $\mathbf{8 b})$, proving that tubulin is indeed the putative target of these compounds.

\subsubsection{Effects on the Cell Cycle}

The effect of the most cytotoxic compounds (1f, $\mathbf{1 h}$ and $\mathbf{3 b}$ ) on the cell cycle profiles of HeLa cells were studied at different time points $(24,48$, and $72 \mathrm{~h}$ ) by flow cytometry, measuring the relative DNA content. Compounds $\mathbf{1 h}$ and $\mathbf{3 b}$ significantly arrested HeLa cells at the $\mathrm{G}_{2} / \mathrm{M}$ phase after a $24-\mathrm{h}$ incubation $\left(68-71 \%\right.$, Figure 2, followed by an increase of the cell population at the subG $G_{0} / G_{1}$ region, suggesting that cell death occurs via apoptosis. In order to assess the cell death mechanism, non-fixed cells were double stained with Annexin V-FITC and propidium iodide (PI), showing that cell death is mainly triggered by apoptosis, which is in agreement with the previous observations (Figure 2). 


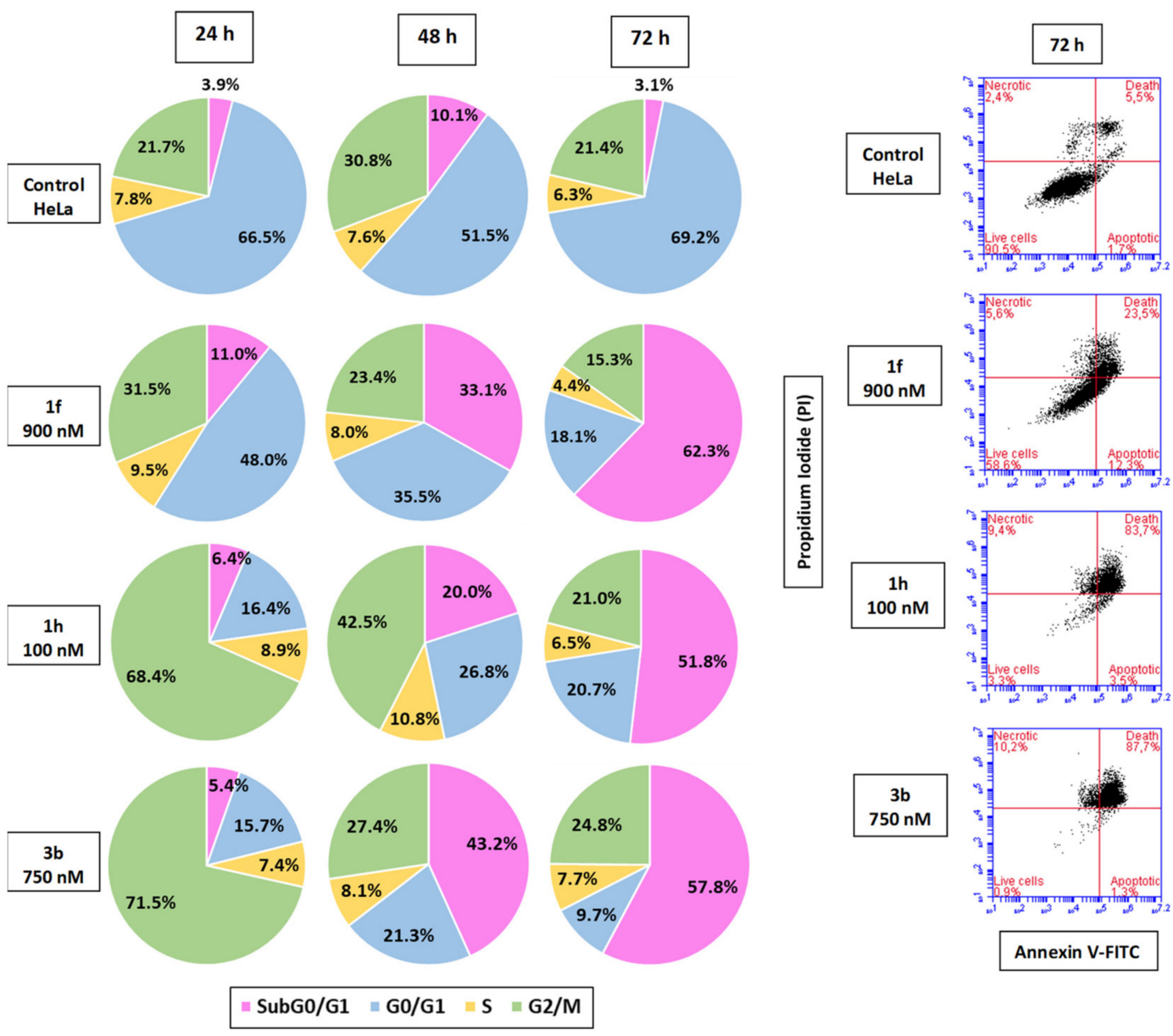

Figure 2. Annexin V-FITC and propidium iodide (PI) profiles, and pie charts of the different cell populations of the cell cycle of HeLa cells after 24, 48, and $72 \mathrm{~h}$ after treatment with the drugs at the indicated doses.

\subsubsection{Effect on Rat Primary Pancreatic Cells}

The toxicity of the compounds against rat primary pancreatic cells was evaluated by the MTT protocol (Table 2) [18]. The compounds showed lower toxicity than doxorubicin, acetyl-digoxin, and etoposide used as positive controls, even at concentrations 5- to 10-fold higher. Sodium taurocholate (NaTc) was also used at high concentrations as a model of acute pancreatitis in vitro. 
Table 2. Toxicity against rat primary pancreatic cells. Results are expressed as a percentage (means \pm S.E.M.) of live cells with respect to the non-treated control, taken as $100 \%$.

\begin{tabular}{|c|c|c|c|c|c|c|c|c|c|c|c|}
\hline \multicolumn{2}{|c|}{$1 \mathrm{~h}$} & \multicolumn{2}{|c|}{ 1f } & \multicolumn{2}{|c|}{$3 b$} & \multicolumn{2}{|c|}{$8 b$} & \multirow{2}{*}{$\begin{array}{c}\text { NaTc } \\
0.50 \%\end{array}$} & \multirow{2}{*}{$\begin{array}{c}\text { Doxorubicin } \\
0.05 \mu \mathrm{M}\end{array}$} & \multirow{2}{*}{$\begin{array}{c}\text { Acetyldigoxin } \\
0.05 \mu \mathrm{M}\end{array}$} & \multirow{2}{*}{$\begin{array}{c}\text { Etoposide } \\
0.05 \mu \mathrm{M}\end{array}$} \\
\hline $0.50 \mu \mathrm{M}$ & $0.25 \mu \mathrm{M}$ & $0.50 \mu \mathrm{M}$ & $0.25 \mu \mathrm{M}$ & $0.50 \mu \mathrm{M}$ & $0.25 \mu \mathrm{M}$ & $0.50 \mu \mathrm{M}$ & $0.25 \mu \mathrm{M}$ & & & & \\
\hline $102.59 \pm 14.73$ & $103.84 \pm 9.20$ & $95.97 \pm 10.55$ & $106.59 \pm 17.60$ & $94.06 \pm 13.13$ & $112.81 \pm 19.30$ & $91.65 \pm 13.88$ & $94.31 \pm 11.83$ & $24.83 \pm 11.86$ & $53.09 \pm 10.27$ & $84.41 \pm 9.64$ & $89.87 \pm 11.80$ \\
\hline
\end{tabular}




\subsection{Molecular Modelling}

Docking studies were performed with the proposed ligand molecules into the colchicine site of tubulin, using three programs with different scoring functions. The flexibility of the protein was accounted for by employing different tubulin structures: from X-ray structures of 50 complexes with different ligands in the colchicine site, and from selected representative snapshots of molecular dynamic simulations. For pose selection, a consensus score strategy was followed, therefore selecting those poses that are best scored by a combination of the three programs. In most cases, the ligands bind within the colchicine site in a similar way as combretastatin A4, with their trimethoxyphenyl rings close to the trimetoxyphenyl ring of combretastatin A4, and the nitrogenated phenyl rings placed in the 3-hydroxy-4-methoxyphenyl ring of combretastatin A4 pocket. Ammonium salts bind with a much lower affinity than their neutral analogues, and pyridines were bound in a very similar way as their phenyl counterparts, with the pyridine nitrogen hidden from the molecular surface by the bulky substituents, which interact favorably with the hydrophobic walls of the site.

\section{Discussion}

Combretastin A4 is arguably the most successful representative so far of the family of the colchicine site ligands [4,5]. However, the 3-hydroxy group of combretastatin A4 that provides an anchor for phosphate prodrug formulation is used by tumor cells for conjugation and development of resistance $[9,19]$. The replacement of the 3-hydroxy-4-methoxyphenyl ring of combretastatins, isocombretastatins and phenstatins by indoles [11-14,20,21], naphthalenes [13], and 4-dimethylaminophenyl rings [15,16,22], results in potent tubulin inhibitory and cytotoxic compounds, but require further elaboration in order to achieve improved water solubility $[10,23]$. An alternative to prodrug formation is the introduction of polar functions, which has been attempted by replacing the phenyl rings of combretastatins, isocombretastatins, and related compounds, with pyridine rings, yielding better results as A than as $\mathrm{B}$ rings $[15,22,24-26]$. This likely reflects the more hydrophobic nature of the pocket, and the energy penalty associated with the desolvation of these polar groups. Here, we propose a new strategy analogous to the intramolecular hydrogen bond concept, consisting on masquerading the hydrogen bond donor and the acceptor pairs in apolar environments by means of mutual interaction, which renders the molecules more hydrophobic. We propose the introduction of polar moieties on the structure of combretastatin analogues, such as the previously attempted pyridines, but masking them in the apolar environment by means of substituents, which hide them from the molecular surface: a strategy we have called masked polar group incorporation (MPGI). For the masking group we have selected alkylamino groups that have been previously shown to interact favorably with zone B, such as the dimethylamino indicated above. Earlier attempts of introducing pyridines with substituents such as 2-methoxypyridines would require the freezing of the methoxy group rotation for the masking of the pyridine nitrogen, and this might cause the observed reduction in potency [22].

With the aim of testing the aforementioned proposal in different scaffold contexts which have been shown to result in different structure-activity relationships $[7,10,11,23,27]$, we have synthesized a new family of combretastatins (8), phenstatins (1), isocombretastatins (3), 1,1-diarylethanes (4), and diaryloxime derivatives (2) with a pyridine B-ring ortho substituted with dialkylamino groups and their phenyl counterparts for the sake of comparison. As a further extension of the strategy, ammonium salts of the dialkylamino substituents have been prepared $(5-7,9)$, as they have polar (charged) groups surrounded by a hydrophobic cap. The synthetic strategies applied have been extensively described for the indicated compound classes. The combretastatins have been prepared by Wittig olefination reactions, the benzophenones by additions of organolithium aryls to carbonyls, and the oximes and isocombretastatins (1,1-diarylethenes) by the reaction of the corresponding benzophenones with hydroxylamine, and by Wittig olefination, respectively. Catalytic hydrogenation of the isocombretastatins produced the corresponding 1,1-diarylethanes in good yields. The ammonium salts were prepared by alkylation of the corresponding amines with methyl iodide. 
The thermodynamic solubility of the synthesized compounds has been measured by the shaking flash methodology. All the compounds measured showed higher aqueous solubilities than combretastatin A4 $(1 \mu \mathrm{g} / \mathrm{mL})$. With respect to the bridge between the aromatic rings, the hydroxylamine derivatives showed the higher solubility, followed by the olefins, and the ketones were the least soluble. The high solubility of the oximes could be attributed to the polar nature of the bridge, but in previous studies related oximes showed the lowest solubilities $[10,16]$. Within the oximes, the 3-dimethylaminopyridine $(\mathbf{2 g})$ and 3-dimethylaminophenyl (2f) analogues showed a notable increase in solubility with respect to the 4-dimethylamino analogue $\mathbf{2 a}$, with $\mathbf{2} \mathbf{g}$ in the $0.6 \mathrm{mg} / \mathrm{mL}$ range. This great improvement is probably due to the symmetry reduction [28], combined with an increased polarity for $\mathbf{2 g}$. All ammonium salts showed huge solubility improvements, with values in the $\mu \mathrm{M}$ range in all cases.

The antiproliferative activity of the compounds against three human tumor cell lines of different origins (i.e., HeLa cervix epithelioid carcinoma, HT-29 colon adenocarcinoma and MCF-7 breast adenocarcinoma) was evaluated by the MTT method. Sixteen out of the 40 tested compounds showed micromolar or less proliferation inhibitory potency. This ratio is improved to more than 50\% (16 out of 31) if the ammonium salts are not considered, as they are all inactive. This high success rate is the result of a combination of favorable scaffolds and substituents, and it is similar to those of previous reports on related series $[7,10,13,16,23]$. Of the three cell lines, HeLa and MCF-7 showed similar sensitivities, while HT-29 cells were less susceptible. We have previously observed the same trend for related compounds acting at the colchicine site of tubulin $[10,23]$. For this pyridine series, we observed a different potency trend when we compare the 4-amino-3-pyridine and the 3-amino-4-pyridine derivatives. For the first ones, the most potent compounds are the combretastatin and the isocombretastatins, whereas for the second ones, the more potent analogues are the phenstatins. This different behavior is probably a reflection of their different shape, combined with the different geometries imposed by different bridges. We have previously shown that the potency ordering isocombretastatins similar to oximes higher than benzophenones could be explained by the higher conjugation of the ketones with the aromatic rings, which imposes a more planar disposition than those required for high affinity colchicine site binding [10]. For the 3-amino-4-pyridine series, more planar structures are required in order to avoid the bumping of the amino substituents with tubulin out the plane of the aromatic ring, an effect which we have previously shown to impact the potency of 3-substituted indolecombretastatins and dimethylaminophenyl phenstatins [16,23]. This different geometrical disposition of the amino substituents, and the different adaptability of their corresponding pockets in the two series, can also account for the preference of bulkier substituents at position 3, such as the pyrrolidine rather than the smaller dimethylamino. The opposite trend was observed for position 4. The 3,4,5-trimethoxyphenyl ring is strongly preferred over 2,3,4-trimethoxyphenyl, and 2,5-dimethoxyphenyl rings, which have also been found in highly potent colchicine site ligands [20]. The phenyl to pyridine substitution is favorable for the 4-dimethylamino combretastatins (i.e., compare $\mathbf{8 a}$ and $\mathbf{8 b}$ ), and results in the most potent 3-pyrrolidin-1-yl phenstatin (1h). The opposite is observed for the 4-dimethylaminophenyl phenstatins $\mathbf{1 a}$ and $\mathbf{1 b}$. The highly polar ammonium salts showed $\mathrm{IC}_{50}$ values higher than micromolar, and are considered inactive. The remarkable levels of solubility achieved for the quaternary ammonium salts came unfortunately at the expenses of biological activity.

Acquired resistance to antitumor drugs is one of the more important problems of chemotherapy, also affecting tubulin-targeting drugs [21]. In order to ascertain the impact of multidrug resistance phenotypes on the action of the compounds, we have measured the cell proliferation inhibitory activity of HT-29 cells in the presence of verapamil, a known P-glycoprotein 1/multidrug resistance protein 1 (MDR1) inhibitor at a concentration of $10 \mu \mathrm{M}$, not affecting cell proliferation [29]. Roughly one-third of the active compounds in the screen $(\mathbf{3 b}-\mathbf{c}, 3 \mathbf{h}, \mathbf{8} \mathbf{a}, \mathbf{8 i})$ showed an improvement bigger than 2 -fold after verapamil treatment, thus suggesting that they might be MDR1 substrates. Except for the combretastatin analogues $\mathbf{8} \mathbf{a}$ and $\mathbf{8 i}$, the affected drugs are all pyridine drugs. The most potent compounds of the series (i.e., combretastatin $\mathbf{8 b}$ and ketone $1 \mathrm{~h}$ ) seem not to be MDR1 substrates. 
In order to confirm the tubulin inhibitory mechanism of action of the compounds, we have studied their effect on the in vitro assembly of bovine brain tubulin. Most of the compounds showed modest inhibition of tubulin polymerization at concentrations of $20 \mu \mathrm{M}$, but the most cytotoxic compounds showed moderate to good inhibitory potencies, with combretastatin $\mathbf{8 b}$ and ketone $\mathbf{1 h}$ having the lowest $\mathrm{IC}_{50}$ values of 5.1 and $9.1 \mu \mathrm{M}$, comparable to those of combretastatin $\mathrm{A} 4(1-4 \mu \mathrm{M})$ or reference compound 8a $(3.4 \mu \mathrm{M})$ [16]. The pyridine-containing compounds have higher $\mathrm{IC}_{50}$ values in TPI than their phenyl matched pairs (e.g., compare $\mathbf{8 a}$ and $\mathbf{8 b}$ ), but they still show lower $\mathrm{IC}_{50}$ values in cytotoxicity. This lack of correlation between tubulin inhibition and cytotoxicity has previously been observed for series with different scaffolds and binding sites, and attributed to the accepted theory that the antiproliferative effects are due to interference with tubulin dynamics, and not with their effect on total polymer mass [1,20]. In any case, the tubulin inhibitory mechanism for the most potent compounds $\mathbf{8 b}$ and ketone $\mathbf{1 h}$ is clearly established.

We have studied the effect of $\mathbf{1 f}, \mathbf{1 h}$, and $\mathbf{3 b}$ on the cell cycle of HeLa cells at different time points $\left(24,48\right.$ and $72 \mathrm{~h}$ ) after drug treatment (Figure 2). After $24 \mathrm{~h}$, a significant arrest of about $70 \%$ at the $\mathrm{G}_{2} / \mathrm{M}$ phase is observed for $\mathbf{1 h}$ and $\mathbf{3 b}$, and a more modest one for $\mathbf{1 f}$. After $48 \mathrm{~h}$, the cells are experiencing apoptosis as indicated by subG $0 / G_{1}$ fractions, especially for compound $3 \mathbf{b}(45 \%)$. At a later time point of $72 \mathrm{~h}$, the subG $0 / \mathrm{G}_{1}$ fractions represent more than $50 \%$ of the cells for the three compounds. These results suggest that the compounds arrest the cells at the $G_{2} / M$ phase to different extents, and that this arrest leads to cell death. We have further characterized the cell death by means of flow cytometry using Annexin V/PI. PI is excluded from live cells, and only stains apoptotic or necrotic cells with altered membrane permeability. Apoptotic cells are Annexin V positive, as they have phosphatidylserine exposed on the surface as a result of its translocation from the inner cytoplasmic membrane from the beginning of apoptosis. The combined stain allows therefore to establish whether cells are viable (PI-/AnV-), early apoptotic (PI-/AnV+), or late apoptotic or secondary necrotic (PI+/AnV+). At $72 \mathrm{~h}$, the results are consistent with the cell cycle profiles, with cells already in a $\mathrm{PI}+/ \mathrm{AnV}+$ state. These results suggest that after an arrest at the $\mathrm{G}_{2} / \mathrm{M}$ phase cells suffer apoptosis.

The toxicity of the more antiproliferative compounds $\mathbf{1 f}, \mathbf{1 h}, \mathbf{3 b}$ and $\mathbf{8 b}$ against primary pancreatic cultured cells was measured and compared with doxorubicin (a DNA intercalator), etoposide (a topoisomerase II poison), acetyl-digoxin (a cardiotonic steroid), and sodium taurocholate (an in vitro model of acute pancreatitis). Compounds $\mathbf{1 f}, \mathbf{1 h}, \mathbf{3 b}$ and $\mathbf{8 b}$ showed very low toxicity against primary pancreatic cultured cells (Table 2).

We have performed docking studies in order to determine the binding modes of the synthesized compounds. The protein flexibility was accounted for by using $50 \mathrm{X}$-ray structures of tubulin in complex with different ligands at the colchicine site [20] and five additional ones from a molecular dynamics simulation, and the ligand flexibility was considered explicitly [21]. The binding poses from three docking programs (PLANTS [30], AutoDock [31], and DOCK [32]) with substantially different scoring functions and for each docked ligand, we selected the binding pose that scored higher for the three programs (Supplementary Table S1). Using this consensus score all the tested ligands docked at the zone A with the methoxylated ring and the other ring at zone B (Figure 3). In all cases, the pyridine ring docks into a hydrophobic region of the protein that contacts the hydrophobic substituent nearby and with the pyridine nitrogen in a nonpolar environment, in good agreement with the MPGI strategy. 

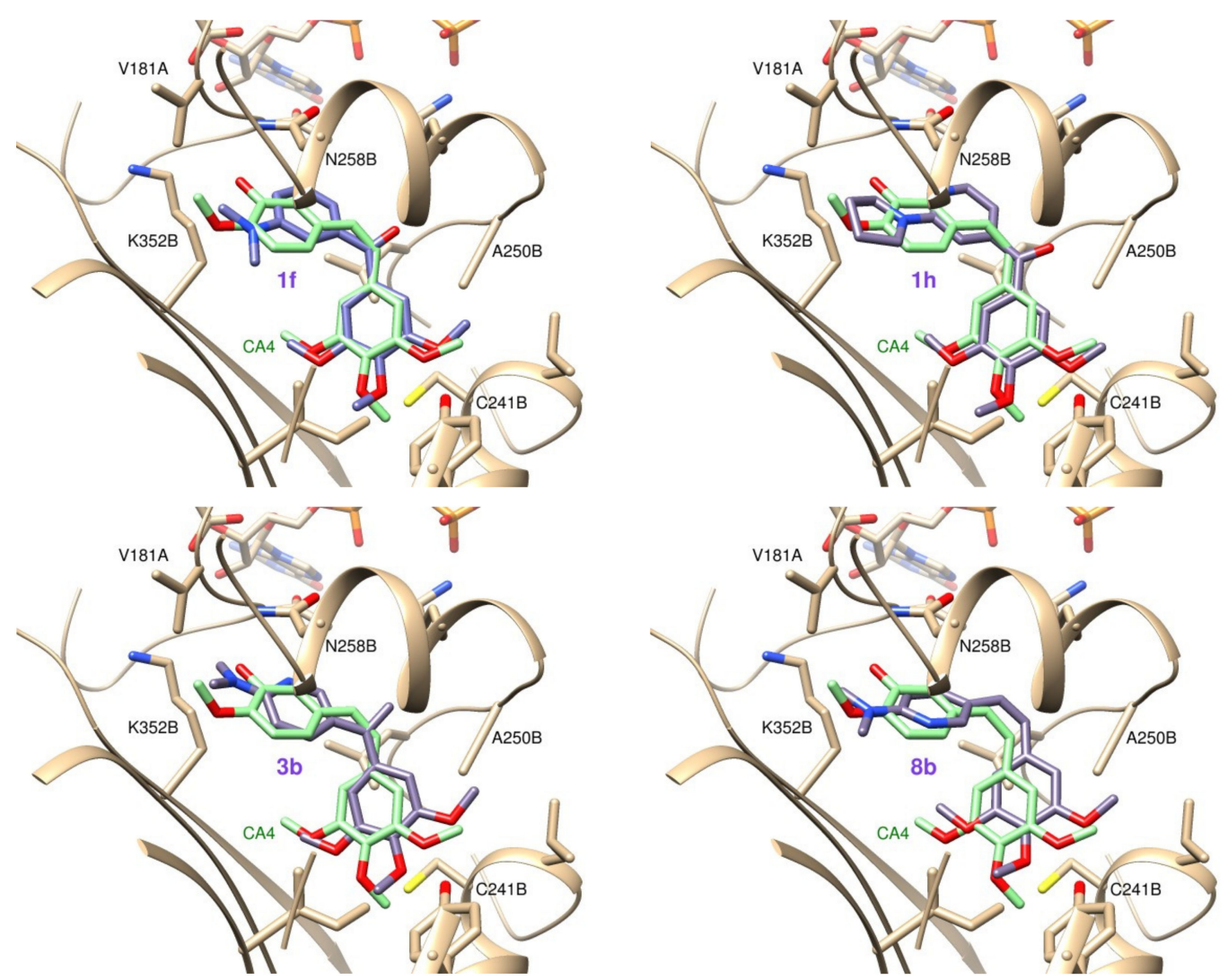

Figure 3. Docking poses for compounds $\mathbf{1 f}, \mathbf{1 h}, \mathbf{3 b}$ and $\mathbf{8 b}$ superimposed with the X-ray pose of CA-4 (light green).

\section{Materials and Methods}

Reagents were used as purchased without further purification. Solvents (THF, DMF, $\mathrm{CH}_{2} \mathrm{Cl}_{2}$ ) were dried and freshly distilled before use according to procedures reported in the literature. Chromatographic separations were performed on silica gel columns by flash (Kieselgel 40, 0.040-0.063; Merck). TLC was performed on precoated silica gel polyester plates $(0.25 \mathrm{~mm}$ thickness, with UV 254 fluorescent indicator). Melting points were determined on a Buchi 510 apparatus and are uncorrected. ${ }^{1} \mathrm{H}$ NMR and ${ }^{13} \mathrm{C}$ NMR spectra were recorded on a Bruker AC200 spectrometer at $200 / 50 \mathrm{MHz}$, on a Bruker SY spectrometer at $400 / 100 \mathrm{MHz}$ or on a Varian Mercury $400 / 100 \mathrm{MHz}$, using $\mathrm{CDCl}_{3}$ as solvent (unless otherwise stated). Chemical shifts $(\delta)$ are given in ppm downfield from tetramethylsilane, and coupling constants ( $J$ values) are in Hertz. Electrospray-ionisation (ESI) high-resolution mass spectra (HRMS) were obtained on a VG-TS250 apparatus (70 eV). A Helios Alfa UV-320 from Thermo-Spectronic was used for UV spectra and turbidimetric measurements. IR spectra were acquired in a FTIR Nicolet Impact 410 equipment (film, unless otherwise stated) and the absorptions are expressed in $\mathrm{cm}^{-1}$. The aqueous solubility of the compound was determined in a Helios Alfa Spectrophotometer.

\subsection{Synthesis}

\subsubsection{General Procedure to Obtain Diarylketones by One-step Synthesis $(\mathbf{1 a}, \mathbf{1} \mathbf{b}, \mathbf{1 f}, \mathbf{1 g})$}

$1.5 \mathrm{mmol}$ per mmol of $1.6 \mathrm{M} \mathrm{nBuLi}$ in hexane was added to a stirred $0.2 \mathrm{M}$ solution of the corresponding bromo derivative in dry THF at $-78^{\circ} \mathrm{C}$ under an inert atmosphere. After $1 \mathrm{~h}$, the colored solution was added to a $0.2 \mathrm{M}$ suspension of the corresponding sodium benzoate in dry THF at $0{ }^{\circ} \mathrm{C}$, previously formed by adding $3 \mathrm{mmol}$ per mmol of sodium hydride over $2 \mathrm{mmol}$ per mmol of the benzoic acid. After $24 \mathrm{~h}$ at room temperature, the reaction was poured onto ammonium chloride, 
extracted with ethyl acetate and the organic layers were dried over anhydrous sodium sulfate, filtered and dried under vacuum. The reaction crude was purified by column chromatography.

(4-(Dimethylamino)phenyl)(3,4,5-trimethoxyphenyl)methanone (1a) [16]. $3.50 \mathrm{~g}$ (17.5 mmol) of $p$-bromodimethylaniline in THF treated with $16.4 \mathrm{~mL}(26.2 \mathrm{mmol})$ of $n \mathrm{BuLi} 1.6 \mathrm{M}$ in hexane at $-78^{\circ} \mathrm{C}$ were added to $35.0 \mathrm{mmol}$ of 3,4,5-trimethoxybenzoate in dry THF to obtain $4.22 \mathrm{~g}$ of reaction crude. After flash chromatography Hex/EtOAc 1:1, $2.50 \mathrm{~g}$ (7.93 mmol, 46\%) of compound 1a were isolated. ${ }^{1} \mathrm{H}-\mathrm{NMR} \delta: 3.06(6 \mathrm{H}, \mathrm{s}) ; 3.85(6 \mathrm{H}, \mathrm{s}) ; 3.90(3 \mathrm{H}, \mathrm{s}) ; 6.66(2 \mathrm{H}, \mathrm{d}, 8.6) ; 6.98(2 \mathrm{H}, \mathrm{s}) ; 7.80(2 \mathrm{H}, \mathrm{d}, 8.6) .{ }^{13} \mathrm{C}-\mathrm{NMR} \delta$ : 40.1 (2) $\left(\mathrm{CH}_{3}\right) ; 56.3(2)\left(\mathrm{CH}_{3}\right) ; 61.0\left(\mathrm{CH}_{3}\right) ; 107.1(2)(\mathrm{CH}) ; 110.6(2)(\mathrm{CH}) ; 124.8(\mathrm{C}) ; 132.7(2)(\mathrm{CH}) ; 134.5(\mathrm{C})$; 140.8 (C); 152.8 (2) (C); 153.3 (C); 194.4 (C). IR (film): 1681; 1583; 1411; 1328; $1121 \mathrm{~cm}^{-1}$. Mp (Diisopropylether): 107-109 ${ }^{\circ} \mathrm{C}$. HRMS: calculated for $\mathrm{C}_{18} \mathrm{H}_{21} \mathrm{NO}_{4}[\mathrm{M}+\mathrm{Na}]^{+}$: 338.1368; found: 338.1363 .

(6-(Dimethylamino)pyridin-3-yl)(3,4,5-trimethoxyphenyl)methanone (1b). $627 \mathrm{mg}(3.12 \mathrm{mmol})$ of 5-bromo$\mathrm{N}, \mathrm{N}$-dimethylpiridin-2-amine in THF treated with $1.9 \mathrm{~mL}(3.1 \mathrm{mmol})$ of $n \mathrm{BuLi} 1.6 \mathrm{M}$ in hexane at $-78^{\circ} \mathrm{C}$ were added to $6.22 \mathrm{mmol}$ of 3,4,5-trimethoxybenzoate in dry THF to obtain $1.25 \mathrm{~g}$ of reaction crude. After flash chromatography Hex/EtOAc 9:1, $833 \mathrm{mg}(2.63 \mathrm{mmol}, 84 \%)$ of compound $\mathbf{1 b}$ were isolated. ${ }^{1} \mathrm{H}-\mathrm{NMR}$ 8: $3.20(6 \mathrm{H}, \mathrm{s}) ; 3.88(6 \mathrm{H}, \mathrm{s}) ; 3.91(3 \mathrm{H}, \mathrm{s}) ; 6.56(1 \mathrm{H}, \mathrm{d}, 9,2) ; 6.99(2 \mathrm{H}, \mathrm{s}) ; 8.01(1 \mathrm{H}, \mathrm{dd}$, 9.2, 2.4); $8.63(1 \mathrm{H}, \mathrm{d}, 2.4) .{ }^{13} \mathrm{C}-\mathrm{NMR} \delta: 38.2(2)\left(\mathrm{CH}_{3}\right) ; 56.3(2)\left(\mathrm{CH}_{3}\right) ; 60.9\left(\mathrm{CH}_{3}\right) ; 105.1(\mathrm{CH}) ; 107.0(2)$ (CH); 121.2 (C); 133.7 (C); $138.8(\mathrm{CH}) ; 143.4$ (C); $152.4(\mathrm{CH}) ; 152.8$ (2) (C); 160.4 (C); $187.6(\mathrm{C})$. IR (KBr): 1686; 1608; 1584; 1508; 1403; 1337; $1132 \mathrm{~cm}^{-1}$. Mp (Diisopropylether): $119-120{ }^{\circ} \mathrm{C}$. HRMS: calculated for $\mathrm{C}_{17} \mathrm{H}_{21} \mathrm{~N}_{2} \mathrm{O}_{4}[\mathrm{M}+\mathrm{H}]^{+}$: 317.1501; found: 317.1507.

(3-(Dimethylamino)phenyl)(3,4,5-trimethoxyphenyl)methanone (1f). $2.78 \mathrm{~g}(13.9 \mathrm{mmol})$ of 3-bromodimethylaniline in THF treated with $9.5 \mathrm{~mL}(15 \mathrm{mmol})$ of $n \mathrm{BuLi} 1.6 \mathrm{M}$ in hexane at $-78^{\circ} \mathrm{C}$ were added to $20.8 \mathrm{mmol}$ of 3,4,5-trimethoxybenzoate in dry THF to obtain $3.27 \mathrm{~g}$ of reaction crude. After flash chromatography Hex/EtOAc 7:3, $3.27 \mathrm{~g}(10.4 \mathrm{mmol}, 75 \%)$ of compound $\mathbf{1 f}$ were isolated. ${ }^{1} \mathrm{H}-\mathrm{NMR} \delta: 2.89(6 \mathrm{H}, \mathrm{s}) ; 3.76(6 \mathrm{H}$, s); $3.83(3 \mathrm{H}, \mathrm{s}) ; 6.82(1 \mathrm{H}, \mathrm{dd}, 8.0,2.8) ; 6.95(1 \mathrm{H}, \mathrm{bd}, 8.0) ; 6.99(2 \mathrm{H}, \mathrm{s}) ; 7.04(1 \mathrm{H}, \mathrm{bs}) ; 7.29(1 \mathrm{H}, \mathrm{t}, 8.0)$. ${ }^{13} \mathrm{C}-\mathrm{NMR}$ 8: $40.5(2)\left(\mathrm{CH}_{3}\right) ; 56.3(2)\left(\mathrm{CH}_{3}\right) ; 61.0\left(\mathrm{CH}_{3}\right) ; 107.8(2)(\mathrm{CH}) ; 113.2(\mathrm{CH}) ; 116.2(\mathrm{CH}) ; 118.3$ (CH); 128.8 (CH); 133.0 (C); 138.5 (C); 141.8 (C); 150.4 (C); 152.8 (2) (C); 196.4 (C). IR (KBr): 1650; 1589; $1412 ; 1334 ; 1230 ; 1124 \mathrm{~cm}^{-1}$. Mp (methanol): $77-78{ }^{\circ} \mathrm{C}$. HRMS: calculated for $\mathrm{C}_{18} \mathrm{H}_{21} \mathrm{NO}_{4}[\mathrm{M}+\mathrm{Na}]^{+}$: 338.1368; found: 338.1361 .

(2-(Dimethylamino)pyridin-4-yl)(3,4,5-trimethoxyphenyl)methanone (1g). $713 \mathrm{mg}$ (3.54 mmol) of 4-bromo$\mathrm{N}, \mathrm{N}$-dimethylpyridin-2-amine in THF treated with $2.9 \mathrm{~mL}(4.6 \mathrm{mmol})$ of $n \mathrm{BuLi} 1.6 \mathrm{M}$ in hexane at $-78{ }^{\circ} \mathrm{C}$ were added to $7.07 \mathrm{mmol}$ of 3,4,5-trimethoxybenzoate in dry THF to obtain $874 \mathrm{mg}$ of reaction crude. After flash chromatography Hex/EtOAc 7:3, $282 \mathrm{mg}(0.90 \mathrm{mmol}, 26 \%)$ of compound $1 \mathrm{~g}$ were isolated. ${ }^{1} \mathrm{H}-\mathrm{NMR} \delta: 3.13(6 \mathrm{H}, \mathrm{s}) ; 3.86(6 \mathrm{H}, \mathrm{s}) ; 3.93(3 \mathrm{H}, \mathrm{s}) ; 6.72(1 \mathrm{H}, \mathrm{d}, 9.4) ; 6.75(1 \mathrm{H}, \mathrm{d}, 2.2) ; 7.10(2 \mathrm{H}$, s); $8.27(1 \mathrm{H}, \mathrm{dd}, 9.4,2.2) .{ }^{13} \mathrm{C}-\mathrm{NMR} \delta: 37.9(2)\left(\mathrm{CH}_{3}\right) ; 56.1(2)\left(\mathrm{CH}_{3}\right) ; 60.7\left(\mathrm{CH}_{3}\right) ; 105.0(\mathrm{CH}) ; 107.6(2)$ (CH); $110.4(\mathrm{CH}) ; 131.2$ (C); 142.5 (C); 146.1 (C); 148.1 (CH); 152.8 (2) (C); 159.3 (C); 194.9 (C). IR (film): $1659 ; 1595 ; 1411 ; 1328 ; 1125 \mathrm{~cm}^{-1}$. Mp (Hexane/Ethyl acetate): $101-102{ }^{\circ} \mathrm{C}$. HRMS: calculated for $\mathrm{C}_{17} \mathrm{H}_{21} \mathrm{~N}_{2} \mathrm{O}_{4}[\mathrm{M}+\mathrm{H}]^{+}:$317.1501; found: 317.1498

\subsubsection{General Procedure to Obtain Diarylketones by Two-step Synthesis (1c, $\mathbf{1 d}, \mathbf{1 e}, \mathbf{1 h})$}

$1.2 \mathrm{mmol}$ per mmol of $1.6 \mathrm{M} \mathrm{nBuLi}$ in hexane was added to a stirred $0.2 \mathrm{M}$ suspension of the corresponding bromo derivative in dry THF at $-78{ }^{\circ} \mathrm{C}$ under inert atmosphere. After $1-2 \mathrm{~h}$, the corresponding aromatic aldehyde was slowly added to the resulting yellowish solution, allowing the reaction to slowly reach room temperature. After $12-24 \mathrm{~h}$, the mixture was poured over ice and extracted with $\mathrm{CH}_{2} \mathrm{Cl}_{2}$. The organic layers were dried over anhydrous $\mathrm{Na}_{2} \mathrm{SO}_{4}$, filtered, and evaporated under vacuum. Then, $1 \mathrm{mmol}$ of PDC per mmol of crude and a small amount of tetrabutylammonium hydrogen sulfate were added in the dark to a $0.15-0.25 \mathrm{M}$ solution of the alcohol in $\operatorname{dry} \mathrm{CH}_{2} \mathrm{Cl}_{2}$ at $0{ }^{\circ} \mathrm{C}$. The reaction was allowed to reach room temperature and proceed until completion (TLC) for 
4-24 h. The reaction crude was filtered through silica, using $\mathrm{CH}_{2} \mathrm{Cl}_{2}$ and ethyl acetate as eluents, and the organic layers evaporated under vacuum to yield the diarylketones that were purified by column chromatography.

(6-(Pyrrolidin-1-yl)pyridin-3-yl)(3,4,5-trimethoxyphenyl)methanone (1c). $500 \mathrm{mg}$ (2.84 mmol) of 6-(pyrrolidin1-yl)nicotinaldehyde were added to a suspension of $840 \mathrm{mg}$ ( $3.40 \mathrm{mmol}$ ) of 5-bromo-1,2,3-trimethoxybenzene and $2.6 \mathrm{~mL}$ ( $4.2 \mathrm{mmol}$ ) of $n \mathrm{BuLi}$ (1.6 M in hexane) in dry THF. After quenching and extraction of the crude, $393 \mathrm{mg}(1.76 \mathrm{mmol})$ of PDC were added. After $4 \mathrm{~h}$ the crude was chromatographed $\mathrm{CH}_{2} \mathrm{Cl}_{2} / \mathrm{EtOAc} 1: 1$ to obtain $450 \mathrm{mg}(1.31 \mathrm{mmol}, 75 \%)$ of $1 \mathrm{c} .{ }^{1} \mathrm{H}-\mathrm{NMR} \delta: 2.03(4 \mathrm{H}, \mathrm{m}) ; 3.54(4 \mathrm{H}, \mathrm{m}) ; 3.86(6 \mathrm{H}, \mathrm{s}) ; 3.89(3 \mathrm{H}, \mathrm{s})$; $6.40(1 \mathrm{H}, \mathrm{d}, 8.8) ; 6.98(2 \mathrm{H}, \mathrm{s}) ; 7.98(1 \mathrm{H}, \mathrm{d}, 8.8) ; 8.62(1 \mathrm{H}, \mathrm{s}) .{ }^{13} \mathrm{C}-\mathrm{NMR} \delta: 25.4(2)\left(\mathrm{CH}_{2}\right) ; 47.0(2)\left(\mathrm{CH}_{2}\right)$; $56.2(2)\left(\mathrm{CH}_{3}\right) ; 60.9\left(\mathrm{CH}_{3}\right) ; 106.0(\mathrm{CH}) ; 107.0(2)(\mathrm{CH}) ; 121.1(\mathrm{C}) ; 133.7(\mathrm{C}) ; 138.5(\mathrm{CH}) ; 141.0(\mathrm{C}) ; 152.8(2)$ (C); 152.9 (CH); 158.3 (C); 193.1 (C). IR (KBr): 1640; 1548; 1330; $1127 \mathrm{~cm}^{-1}$. Mp (diethyl ether): 140-141 ${ }^{\circ} \mathrm{C}$. HRMS: calculated for $\mathrm{C}_{19} \mathrm{H}_{23} \mathrm{~N}_{2} \mathrm{O}_{4}[\mathrm{M}+\mathrm{H}]^{+}$: 343.1658; found: 343.1651 .

(4-(Dimethylamino)phenyl)(2,3,4-trimethoxyphenyl)methanone (1d). $4.43 \mathrm{~g}$ (29.7 mmol) of 4-(dimethylamine) benzaldehyde were added to a suspension of $5.00 \mathrm{~g}(29.7 \mathrm{mmol})$ of 6-bromo-1,2,3-trimethoxybenzene and $18.6 \mathrm{~mL}$ ( $29.7 \mathrm{mmol})$ of $n \mathrm{BuLi}$ (1.6 M in hexane) in dry THF. After quenching and extraction of the crude, $16.8 \mathrm{~g}$ ( $44.7 \mathrm{mmol})$ of PDC were added. After $24 \mathrm{~h}$ the crude was chromatographed Hex/EtOAc 8:2 to obtain $1.86 \mathrm{~g}(5.90 \mathrm{mmol}, 20 \%)$ of $1 \mathrm{~d} .{ }^{1} \mathrm{H}-\mathrm{NMR} \delta: 3.02(6 \mathrm{H}, \mathrm{s}) ; 3.76(3 \mathrm{H}, \mathrm{s}) ; 3.87(6 \mathrm{H}, \mathrm{s}) ; 6.60(2 \mathrm{H}, \mathrm{d}$, 9.0); $6.67(1 \mathrm{H}, \mathrm{d}, 8.6) ; 7.01(1 \mathrm{H}, \mathrm{d}, 8.6) ; 7.72(2 \mathrm{H}, \mathrm{d}, 9.0) .{ }^{13} \mathrm{C}-\mathrm{NMR} \delta: 40.1(2)\left(\mathrm{CH}_{3}\right) ; 56.1\left(\mathrm{CH}_{3}\right) ; 61.1$ $\left(\mathrm{CH}_{3}\right) ; 61.9\left(\mathrm{CH}_{3}\right) ; 106.8(\mathrm{CH}) ; 110.5(2)(\mathrm{CH}) ; 124.2(\mathrm{CH}) ; 125.5(\mathrm{C}) ; 127.7(\mathrm{C}) ; 132.4(2)(\mathrm{CH}) ; 142.0(\mathrm{C}) ;$ 152.0 (C); 153.5 (C); 155.0 (C); 193.6 (C). IR (KBr): 1636; $1588 \mathrm{~cm}^{-1}$. Mp (Hexane/ $\left.\mathrm{CH}_{2} \mathrm{Cl}_{2}\right): 205-207^{\circ} \mathrm{C}$. HRMS: calculated for $\mathrm{C}_{18} \mathrm{H}_{21} \mathrm{NO}_{4}[\mathrm{M}+\mathrm{Na}]^{+}$: 338.1368; found: 338.1360 .

(2,5-dimethoxyphenyl)(4-(dimethylamino)phenyl)methanone (1e). $5.40 \mathrm{~g}$ (36.2 mmol) of 4-(dimethylamine) benzaldehyde were added to a suspension of $5.02 \mathrm{~g}$ ( $36.2 \mathrm{mmol})$ of 2-bromo-1,4-dimethoxybenzene and $22.6 \mathrm{~mL}$ ( $36.2 \mathrm{mmol})$ of $n \mathrm{BuLi}$ (1.6 M in hexane) in dry THF. After quenching and extraction of the crude, $22.05 \mathrm{~g}(58.6 \mathrm{mmol})$ of PDC were added. After $24 \mathrm{~h}$ the crude was chromatographed Hex/EtOAc 8:2 to obtain $3.52 \mathrm{~g}(12.40 \mathrm{mmol}, 32 \%)$ of 1 e. ${ }^{1} \mathrm{H}-\mathrm{NMR} \delta: 3.03(6 \mathrm{H}, \mathrm{s}) ; 3.68(3 \mathrm{H}, \mathrm{s}) ; 3.75(3 \mathrm{H}, \mathrm{s}) ; 6.61(2 \mathrm{H}, \mathrm{d}, 8.8)$; $6.85(1 \mathrm{H}, \mathrm{d}, 2.5) ; 6.90(1 \mathrm{H}, \mathrm{dd}, 8.8,2.5) ; 6.92(1 \mathrm{H}, \mathrm{d}, 8.8) ; 7.74(2 \mathrm{H}, \mathrm{d}, 8.8) .{ }^{13} \mathrm{C}-\mathrm{NMR} \delta: 40.0(2)\left(\mathrm{CH}_{3}\right)$; $55.8\left(\mathrm{CH}_{3}\right) ; 56.5\left(\mathrm{CH}_{3}\right) ; 110.4(2)(\mathrm{CH}) ; 113.0(\mathrm{CH}) ; 114.1(\mathrm{CH}) ; 115.9(\mathrm{CH}) ; 125.1(\mathrm{C}) ; 130.9(\mathrm{C}) ; 132.3$ (2) (CH); 150.9 (C); 153.3 (C); 153.5 (C); 194.0 (C). IR (KBr): 1637; 1588; $1544 \mathrm{~cm}^{-1}$. Mp (t-butylmethyl ether): $78-80^{\circ} \mathrm{C}$. HRMS: calculated for $\mathrm{C}_{17} \mathrm{H}_{20} \mathrm{NO}_{3}[\mathrm{M}+\mathrm{H}]^{+}$: 286.1443; found: 286.1420 .

(2-(Pyrrolidin-1-yl)pyridin-4-yl)(3,4,5-trimethoxyphenyl)methanone (1h). $1.00 \mathrm{~g}$ (5.67 mmol) of 2-(pyrrolidin-1-yl) isonicotinaldehyde were added to a suspension of $2.15 \mathrm{~g}$ ( $8.51 \mathrm{mmol})$ of 5-bromo-1,2,3-trimethoxybenzene and $6.40 \mathrm{~mL}(10.2 \mathrm{mmol})$ of $n \mathrm{BuLi}(1.6 \mathrm{M}$ in hexane) in dry THF. After quenching and extraction of the crude, $0.78 \mathrm{~g}(14.2 \mathrm{mmol})$ of PDC were added. After $4 \mathrm{~h}$ the crude was chromatographed with $\mathrm{CH}_{2} \mathrm{Cl}_{2} / \mathrm{MeOH}$ 98:2 to obtain $735 \mathrm{mg}(2.15 \mathrm{mmol}, 38 \%)$ of $1 \mathrm{~h} .{ }^{1} \mathrm{H}-\mathrm{NMR} \delta: 1.98(4 \mathrm{H}, \mathrm{m}) ; 3.43(4 \mathrm{H}, \mathrm{m}) ; 3.82(6 \mathrm{H}, \mathrm{s}) ; 3.89$ $(3 \mathrm{H}, \mathrm{s}) ; 6.55(1 \mathrm{H}, \mathrm{s}) ; 6.60(1 \mathrm{H}, \mathrm{d}, 5.6) ; 7.07(2 \mathrm{H}, \mathrm{s}) ; 8.20(1 \mathrm{H}, \mathrm{d}, 5.6) .{ }^{13} \mathrm{C}-\mathrm{NMR} \delta: 25.4(2)\left(\mathrm{CH}_{2}\right) ; 46.8(2)$ $\left(\mathrm{CH}_{2}\right) ; 56.2(2)\left(\mathrm{CH}_{3}\right) ; 60.9\left(\mathrm{CH}_{3}\right) ; 106.0(\mathrm{CH}) ; 107.7(2)(\mathrm{CH}) ; 110.1(\mathrm{CH}) ; 131.2(\mathrm{C}) ; 146.1(\mathrm{C}) ; 148.1(\mathrm{CH})$; 152.9 (2) (C); 155.0 (C); 157.1 (C); 195.1 (C). IR (film): 1650; 1598; 1538; 1456; 1328; $1127 \mathrm{~cm}^{-1}$. HRMS: calculated for $\mathrm{C}_{19} \mathrm{H}_{23} \mathrm{~N}_{2} \mathrm{O}_{4}[\mathrm{M}+\mathrm{H}]^{+}$: 343.1658; found: 343.1642 .

\subsubsection{General Procedure to Obtain Oxime Derivatives ( $\mathbf{2} \mathbf{a}-\mathbf{h})$}

3-15 mmol of $\mathrm{NH}_{2} \mathrm{OH} \cdot \mathrm{HCl}$ per mmol of diarylketone and 2-4 droplets of pyridine were added to a $0.02-0.06 \mathrm{M}$ solution of the corresponding diarylketone in $10-25 \mathrm{~mL}$ of $\mathrm{MeOH}$, and the reaction was refluxed for 12-48 h. After cooling, the solvent was evaporated off, the residue was re-dissolved in $\mathrm{CH}_{2} \mathrm{Cl}_{2}$, washed with brine, and the organic layers were dried, filtered, and evaporated. 
(4-(Dimethylamino)phenyl)(3,4,5-trimethoxyphenyl)methanone oxime (2a) [16]. $560 \mathrm{mg}$ (7.93 mmol) of hydroxylamine hydrochloride were added to $500 \mathrm{mg}(1.59 \mathrm{mmol})$ of ketone 1a in methanol to obtain, after crystallization in $\mathrm{MeOH} / \mathrm{EtOAc}, 300 \mathrm{mg}$ ( $0.91 \mathrm{mmol}, 57 \%)$ of a 45:55 Z/E mixture of 2a. While isomer $E$ crystals are yellow, isomer $Z$ crystals are green, so they were manually separated. $2 \mathbf{a}(E)$ : ${ }^{1} \mathrm{H}-\mathrm{NMR}\left(\mathrm{CD}_{3} \mathrm{OD}\right) \delta: 2.89(6 \mathrm{H}, \mathrm{s}) ; 3.65(6 \mathrm{H}, \mathrm{s}) ; 3.67(3 \mathrm{H}, \mathrm{s}) ; 6.61(2 \mathrm{H}, \mathrm{s}) ; 6.63(2 \mathrm{H}, \mathrm{d}, 8.9) ; 7.25(2 \mathrm{H}, \mathrm{d}, 8.9)$. ${ }^{13} \mathrm{C}-\mathrm{NMR}\left(\mathrm{CD}_{3} \mathrm{OD}\right) \delta: 40.5(2)\left(\mathrm{CH}_{3}\right) ; 56.4(2)\left(\mathrm{CH}_{3}\right) ; 61.1\left(\mathrm{CH}_{3}\right) ; 107.0(2)(\mathrm{CH}) ; 111.7(2)(\mathrm{CH}) ; 121.6(\mathrm{C})$; 132.4 (2) (CH); 135.0 (C); 139.8 (C); 152.1 (C); 154.1 (2) (C); 158.1 (C). Mp. (MeOH/EtOAc): $148-149^{\circ} \mathrm{C}$. HRMS: calculated for $\mathrm{C}_{18} \mathrm{H}_{22} \mathrm{~N}_{2} \mathrm{O}_{4}[\mathrm{M}+\mathrm{Na}]^{+}$: 353.1472; found: 353.1477. 2a (E): ${ }^{1} \mathrm{H}-\mathrm{NMR}\left(\mathrm{CD}_{3} \mathrm{OD}\right)$

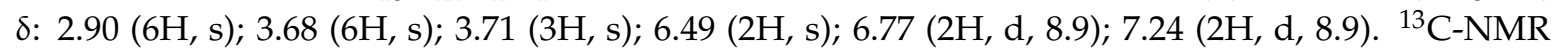
$\left(\mathrm{CD}_{3} \mathrm{OD}\right) \delta: 40.5(2)\left(\mathrm{CH}_{3}\right) ; 56.4(2)\left(\mathrm{CH}_{3}\right) ; 61.1\left(\mathrm{CH}_{3}\right) ; 107.8(2)(\mathrm{CH}) ; 112.3(2)(\mathrm{CH}) ; 121.6(\mathrm{C}) ; 129.7(2)$ (CH); 135.0 (C); 139.8 (C); 152.1 (C); 154.1 (2) (C); 158.1 (C). IR (KBr): 3410; 1604; 1527; $1126 \mathrm{~cm}^{-1}$. Mp (MeOH/EtOAc): $163-164{ }^{\circ} \mathrm{C}$. HRMS: calculated for $\mathrm{C}_{18} \mathrm{H}_{22} \mathrm{~N}_{2} \mathrm{O}_{4}$ [M+Na] ${ }^{+}$: 353.1477; found: 353.1470 .

(6-(Pyrrolidin-1-yl)pyridin-3-yl)(3,4,5-trimethoxyphenyl)methanone oxime (2c). $170 \mathrm{mg}$ (2.46 mmol) of hydroxylamine hydrochloride were added to $56 \mathrm{mg}(0.16 \mathrm{mmol})$ of ketone $1 \mathrm{c}$ in methanol to obtain, after crystallization in $\mathrm{MeOH}, 15 \mathrm{mg}(0.04 \mathrm{mmol}, 25 \%)$ of $2 \mathrm{c} .{ }^{1} \mathrm{H}-\mathrm{NMR} \delta: 2.13(4 \mathrm{H}, \mathrm{m}) ; 3.80(4 \mathrm{H}, \mathrm{m})$; $3.88(6 \mathrm{H}, \mathrm{s}) ; 3.92(3 \mathrm{H}, \mathrm{s}) ; 6.68(1 \mathrm{H}, \mathrm{d}, 8.8) ; 6.99(2 \mathrm{H}, \mathrm{s}) ; 8.22(1 \mathrm{H}, \mathrm{dd}, 8.8,2.0) ; 8.65(1 \mathrm{H}, \mathrm{d}, 2.0)$. IR (KBr): $3490 ; 1610 ; 1590 ; 1430 ; 1380 ; 1210 \mathrm{~cm}^{-1}$.

(4-(Dimethylamino)phenyl)(2,3,4-trimethoxyphenyl)methanone oxime (2d). $862 \mathrm{mg}(12.4 \mathrm{mmol})$ of hydroxylamine hydrochloride were added to $346 \mathrm{mg}(1.10 \mathrm{mmol})$ of ketone $\mathbf{1 d}$ in methanol to obtain, after column chromatography Hex/EtOAc 7:3, $158 \mathrm{mg}(0.48 \mathrm{mmol}, 44 \%)$ of 2 d. ${ }^{1} \mathrm{H}-\mathrm{NMR} \delta: 2.96$ $(6 \mathrm{H}, \mathrm{s}) ; 3.77(3 \mathrm{H}, \mathrm{s}) ; 3.91(6 \mathrm{H}, \mathrm{s}) ; 6.65(2 \mathrm{H}, \mathrm{d}, 7.6) ; 6.77(1 \mathrm{H}, \mathrm{d}, 7.4) ; 6.87(1 \mathrm{H}, \mathrm{d}, 7.4) ; 7.37(2 \mathrm{H}, \mathrm{d}, 7.6)$. ${ }^{13} \mathrm{C}-\mathrm{NMR}$ 8: $40.3(2)\left(\mathrm{CH}_{3}\right) ; 55.9\left(\mathrm{CH}_{3}\right) ; 60.8\left(\mathrm{CH}_{3}\right) ; 60.9\left(\mathrm{CH}_{3}\right) ; 107.2(\mathrm{CH}) ; 108.3(\mathrm{C}) ; 112.1(2)(\mathrm{CH})$; 120.2 (C); 123.7 (CH); 128.0 (2) (CH); 142.2 (C); 151.0 (C); 151.2 (C); 154.05 (C); 155.96(C). IR (KBr): 3490; 1523; $1601 \mathrm{~cm}^{-1}$. $\mathrm{Mp}\left(\mathrm{CH}_{2} \mathrm{Cl}_{2} / \mathrm{Hexane}\right): 179-181^{\circ} \mathrm{C}$. HRMS: calculated for $\mathrm{C}_{18} \mathrm{H}_{22} \mathrm{~N}_{2} \mathrm{O}_{4}[\mathrm{M}+\mathrm{Na}]^{+}$: 353.1477; found: 353.1469 .

(2,5-Dimethoxyphenyl)(4-(dimethylamino)phenyl)methanone oxime (2e). $494 \mathrm{mg}$ (7.1 mmol) of hydroxylamine hydrochloride were added to $223 \mathrm{mg}(0.80 \mathrm{mmol})$ of ketone 1e in methanol to obtain, after column chromatography Hex/EtOAc 8:2, $128 \mathrm{mg}(0.40 \mathrm{mmol}, 50 \%)$ of 2 e. ${ }^{1} \mathrm{H}-\mathrm{NMR} \delta: 2.99\left(6 \mathrm{H}, \mathrm{s}, \mathrm{NCH}_{3}\right) ; 3.73$ $\left(3 \mathrm{H}, \mathrm{s}, \mathrm{OCH}_{3}\right) ; 3.78\left(3 \mathrm{H}, \mathrm{s}, \mathrm{OCH}_{3}\right) ; 6.63(2 \mathrm{H}, \mathrm{d}, 8.0) ; 6.74(1 \mathrm{H}, \mathrm{d}, 7.6) ; 6.95(1 \mathrm{H}, \mathrm{d}, 7.6) ; 7.38(2 \mathrm{H}, \mathrm{d}$, 9.0). ${ }^{13} \mathrm{C}-\mathrm{NMR} \delta: 40.2(2)\left(\mathrm{CH}_{3}\right) ; 55.7\left(\mathrm{CH}_{3}\right) ; 56.7\left(\mathrm{CH}_{3}\right) ; 111.7(2)(\mathrm{CH}) ; 113.0(\mathrm{CH}) ; 114.8(\mathrm{CH}) ; 115.0$ (CH); 123.1 (C); 123.8 (C); 127.9 (2)(CH); 150.6 (C); 151.0 (C); 153.6 (C); 155.7 (C). IR (KBr): 3485, 1525, $1606 \mathrm{~cm}^{-1}$. $\mathrm{Mp}\left(\mathrm{CH}_{2} \mathrm{Cl}_{2} /\right.$ hexane): $163-165^{\circ} \mathrm{C}$. HRMS: calculated for $\mathrm{C}_{17} \mathrm{H}_{21} \mathrm{~N}_{2} \mathrm{O}_{3}[\mathrm{M}+\mathrm{H}]^{+}$: 301.1552; found: 301.1556 .

(3-(Dimethylamino)phenyl)(3,4,5-trimethoxyphenyl)methanone oxime (2f). $220 \mathrm{mg}$ (3.17 mmol) of hydroxylamine hydrochloride were added to $100 \mathrm{mg}(0.32 \mathrm{mmol})$ of ketone $\mathbf{1 f}$ in methanol to obtain $96 \mathrm{mg}(0.29 \mathrm{mmol}$, $91 \%)$ of a 1:1 mixture of Z/E isomers of $2 \mathrm{f} .(\mathrm{Z}):{ }^{1} \mathrm{H}-\mathrm{NMR} \delta: 2.87(6 \mathrm{H}, \mathrm{s}) ; 3.72(6 \mathrm{H}, \mathrm{s}) ; 3.80(3 \mathrm{H}, \mathrm{s}) ; 6.55(2 \mathrm{H}$, s); $6.61(1 \mathrm{H}, \mathrm{d}, 8.0) ; 6.65(1 \mathrm{H}, \mathrm{d}, 8.0) ; 6.72(1 \mathrm{H}, \mathrm{s}) ; 7.26(1 \mathrm{H}, \mathrm{t}, 8.0) .{ }^{13} \mathrm{C}-\mathrm{NMR} \delta: 40.6(2)\left(\mathrm{CH}_{3}\right) ; 56.2(2)$ $\left(\mathrm{CH}_{3}\right) ; 60.9\left(\mathrm{CH}_{3}\right) ; 106.7(2)(\mathrm{CH}) ; 113.1(\mathrm{CH}) ; 114.0(\mathrm{CH}) ; 117.3(\mathrm{CH}) ; 128.3(\mathrm{C}) ; 128.9(\mathrm{CH}) ; 133.3(\mathrm{C}) ;$ 136.9 (C); 150.3 (C); 152.9 (2) (C); 158.5 (C). (E): ${ }^{1} \mathrm{H}-\mathrm{NMR} \delta: 2.90(6 \mathrm{H}, \mathrm{s}) ; 3.76(6 \mathrm{H}, \mathrm{s}) ; 3.84(3 \mathrm{H}, \mathrm{s}) ; 6.62$ $(1 \mathrm{H}, \mathrm{s}) ; 6.71(2 \mathrm{H}, \mathrm{s}) ; 6.74(1 \mathrm{H}, \mathrm{d}, 8.0) ; 6.90(1 \mathrm{H}, \mathrm{d}, 8.0) ; 7.13(1 \mathrm{H}, \mathrm{t}, 8.0) .{ }^{13} \mathrm{C}-\mathrm{NMR} \delta: 40.6(2)\left(\mathrm{CH}_{3}\right) ; 56.2$ (2) $\left(\mathrm{CH}_{3}\right) ; 60.9\left(\mathrm{CH}_{3}\right) ; 105.3(2)(\mathrm{CH}) ; 111.8(\mathrm{CH}) ; 113.4(\mathrm{CH}) ; 117.1(\mathrm{CH}) ; 128.3(\mathrm{C}) ; 128.9(\mathrm{CH}) ; 133.3$ (C); 136.9 (C); 150.3 (C); 152.9 (2) (C); 158.1 (C). IR (film): 3428; 1582; 1503; 1411; 1344; 1236; $1127 \mathrm{~cm}^{-1}$. HRMS: calculated for $\mathrm{C}_{18} \mathrm{H}_{23} \mathrm{~N}_{2} \mathrm{O}_{4}[\mathrm{M}+\mathrm{H}]^{+}$: 331.1658; found: 331.1650.

(2-(Dimethylamino)pyridin-4-yl)(3,4,5-trimethoxyphenyl)methanone oxime $(\mathbf{2 g}) .40 \mathrm{mg}(0.54 \mathrm{mmol})$ of hydroxylamine hydrochloride were added to $55 \mathrm{mg}(0.17 \mathrm{mmol})$ of ketone $1 \mathrm{~g}$ in methanol to obtain, after column chromatography with Hex/EtOAc 1:1, $12 \mathrm{mg}(0.04 \mathrm{mmol}, 23 \%)$ of a 4:6 mixture of Z/E 
isomers of 2g. (Z): ${ }^{1} \mathrm{H}-\mathrm{NMR} \delta: 3.11(6 \mathrm{H}, \mathrm{s}) ; 3.86(6 \mathrm{H}, \mathrm{s}) ; 3.91(3 \mathrm{H}, \mathrm{s}) ; 6.61(2 \mathrm{H}, \mathrm{s}) ; 6.66(1 \mathrm{H}, \mathrm{s}) ; 8.13(1 \mathrm{H}$, d, 5.4); $8.25(1 \mathrm{H}, \mathrm{d}, 5.4)$. (E): ${ }^{1} \mathrm{H}-\mathrm{NMR} \delta: 3.16(6 \mathrm{H}, \mathrm{s}) ; 3.79(6 \mathrm{H}, \mathrm{s}) ; 3.83(3 \mathrm{H}, \mathrm{s}) ; 6.47(1 \mathrm{H}, \mathrm{s}) ; 6.50(1 \mathrm{H}, \mathrm{d}$, 5.4); $6.74(2 \mathrm{H}, \mathrm{s}) ; 8.22(1 \mathrm{H}, \mathrm{d}, 5.4) .{ }^{13} \mathrm{C}-\mathrm{NMR} \delta: 38.6(2)\left(\mathrm{CH}_{3}\right) ; 56.2(2)\left(\mathrm{CH}_{3}\right) ; 60.9\left(\mathrm{CH}_{3}\right) ; 104.1(\mathrm{CH})$; 104.8 (2) (CH); 110.0 (CH); 126.7 (C); 130.4 (C); 146.1 (C); $142.3(\mathrm{CH}) ; 153.1$ (2) (C); 156.3 (C); 158.9 (C). IR (film): 3205; 1650; 1586; 1458; 1236; $1125 \mathrm{~cm}^{-1}$. HRMS: calculated for $\mathrm{C}_{17} \mathrm{H}_{22} \mathrm{~N}_{3} \mathrm{O}_{4}[\mathrm{M}+\mathrm{H}]^{+}: 332.1610$; found: 332.1609 .

(2-(Pyrrolidin-1-yl)pyridin-4-yl)(3,4,5-trimethoxyphenyl)methanone oxime (2h). $167 \mathrm{mg}(2.41 \mathrm{mmol})$ of hydroxylamine hydrochloride were added to $275 \mathrm{mg}(0.80 \mathrm{mmol})$ of ketone $1 \mathrm{~h}$ in methanol to obtain, after column chromatography Hex/EtOAc 6:4, $120 \mathrm{mg}(0.34 \mathrm{mmol}, 42 \%)$ of a 4:6 mixture of Z/E isomers of 2 h. (Z): ${ }^{1} \mathrm{H}-\mathrm{NMR} \delta: 1.60(4 \mathrm{H}, \mathrm{m}) ; 3.43(4 \mathrm{H}, \mathrm{m}) ; 3.83(6 \mathrm{H}, \mathrm{s}) ; 3.91(3 \mathrm{H}, \mathrm{s}) ; 6.46(1 \mathrm{H}, \mathrm{d}, 4.6) ; 6.60(1 \mathrm{H}, \mathrm{s})$; $6.61(2 \mathrm{H}, \mathrm{s}) ; 8.14(1 \mathrm{H}, \mathrm{d}, 4.6)$. (E): ${ }^{1} \mathrm{H}-\mathrm{NMR} \delta: 2.02(4 \mathrm{H}, \mathrm{m}) ; 3.47(4 \mathrm{H}, \mathrm{m}) ; 3.80(6 \mathrm{H}, \mathrm{s}) ; 3.87(3 \mathrm{H}, \mathrm{s}) ; 6.30$ $(1 \mathrm{H}, \mathrm{s}) ; 6.42(1 \mathrm{H}, \mathrm{d}, 4.6) ; 6.76(2 \mathrm{H}, \mathrm{s}) ; 8.26(1 \mathrm{H}, \mathrm{d}, 4.6) .{ }^{13} \mathrm{C}-\mathrm{NMR} \delta: 25.5(2)\left(\mathrm{CH}_{2}\right) ; 46.9(2)\left(\mathrm{CH}_{2}\right) ; 56.2(2)$ $\left(\mathrm{CH}_{3}\right) ; 60.9\left(\mathrm{CH}_{3}\right) ; 104.9(2)(\mathrm{CH}) ; 114.6(\mathrm{CH}) ; 119.5(\mathrm{CH}) ; 130.2(\mathrm{C}) ; 139.6(\mathrm{C}) ; 142.7(\mathrm{C}) ; 147.7(\mathrm{CH})$; 153.0 (2) (C); $155.4(\mathrm{C}) ; 155.4(\mathrm{C})$. IR (KBr): 3433; 1605; 1542; 1238; $1127 \mathrm{~cm}^{-1}$. HRMS: calculated for $\mathrm{C}_{19} \mathrm{H}_{24} \mathrm{~N}_{3} \mathrm{O}_{4}[\mathrm{M}+\mathrm{H}]^{+}$: 358.1767; found: 358.1769.

\subsubsection{General Procedure to Obtain Isocombretastatines by Wittig Reactions (3a-h)}

The required methyltriphenylphosphonium iodide ( $3 \mathrm{mmol} / \mathrm{mmol}$ of diarylketone) was suspended in dry THF (30-60 mL) and cooled to $-40^{\circ} \mathrm{C}$ under inert atmosphere, $n$ Butyllithium (1.6 $\mathrm{M}$ in hexane, 0.9 equivalents respect to the salt) was added drop wise, and the resulting solution was stirred at this temperature for $60 \mathrm{~min}$ turning from deep-red to yellow-red. Then, a solution of the diarylketone in dry THF (15 mL) was added and warmed to room temperature. Once completed, the reaction mixture was poured onto ammonium chloride and extracted with ethyl acetate. The organic layers were washed with brine, dried over sodium sulfate and concentrated under vacuum. The residue was purified by column chromatography on silica gel.

N,N-Dimethyl-4-(1-(3,4,5-trimethoxyphenyl)vinyl)aniline (3a) [16]. A solution of $1.40 \mathrm{~g}$ (4.44 mmol) of 1a in THF was added to a suspension of $5.40 \mathrm{~g}(13.3 \mathrm{mmol})$ of methyltriphenylphosphonium iodide and $6.90 \mathrm{~mL}(11.0 \mathrm{mmol})$ of $n \mathrm{BuLi}\left(1.6 \mathrm{M}\right.$ in hexane) in dry THF at $-40{ }^{\circ} \mathrm{C}$ to obtain, after column chromatography with Hex/EtOAc 6:4, $1.05 \mathrm{~g}$ (3.35 mmol, 75\%) of compound 3a. ${ }^{1} \mathrm{H}-\mathrm{NMR} \delta: 2.93(6 \mathrm{H}$, s); $3.80(6 \mathrm{H}, \mathrm{s}) ; 3.90(3 \mathrm{H}, \mathrm{s}) ; 5.24(1 \mathrm{H}, \mathrm{d}, 1.4) ; 5.36(1 \mathrm{H}, \mathrm{d}, 1.4) ; 6.62(2 \mathrm{H}, \mathrm{s}) ; 6.65(2 \mathrm{H}, \mathrm{d}, 8.6) ; 7.23(2 \mathrm{H}, \mathrm{d}$, 8.6). ${ }^{13} \mathrm{C}-\mathrm{NMR} \delta: 40.4(2)\left(\mathrm{CH}_{3}\right) ; 56.1(2)\left(\mathrm{CH}_{3}\right) ; 60.9\left(\mathrm{CH}_{3}\right) ; 105.8(2)(\mathrm{CH}) ; 110.9\left(\mathrm{CH}_{2}\right) ; 111.9(2)(\mathrm{CH})$; 129.1 (2) (CH); 137.6 (C); 138.1 (2) (C); 149.9 (C); 150.3(C); 152.9 (2) (C). IR (film): 1605; 1579; 1516; 1350; 1126; $1008 \mathrm{~cm}^{-1}$. HRMS: calculated for $\mathrm{C}_{19} \mathrm{H}_{24} \mathrm{NO}_{3}[\mathrm{M}+\mathrm{H}]^{+}: 314.1756$; found: 314.1755 .

N,N-Dimethyl-5-(1-(3,4,5-trimethoxyphenyl)vinyl)pyridin-2-amine (3b). A solution of $127 \mathrm{mg}(0.40 \mathrm{mmol})$ of $\mathbf{1 b}$ in THF was added to a suspension of $485 \mathrm{mg}(1.20 \mathrm{mmol})$ of methyltriphenylphosphonium iodide and $0.23 \mathrm{~mL}(1.0 \mathrm{mmol})$ of $n \mathrm{BuLi}(1.6 \mathrm{M}$ in hexane $)$ in dry THF at $-40{ }^{\circ} \mathrm{C}$ to obtain, after column chromatography with Hex/EtOAc 7:3, $51 \mathrm{mg}(0.2 \mathrm{mmol}, 41 \%)$ of compound $3 \mathrm{~b} .{ }^{1} \mathrm{H}-\mathrm{NMR} \delta: 3.12(6 \mathrm{H}$, s); $3.82(6 \mathrm{H}, \mathrm{s}) ; 3.86(3 \mathrm{H}, \mathrm{s}) ; 5.25(1 \mathrm{H}, \mathrm{s}) ; 5.33(1 \mathrm{H}, \mathrm{s}) ; 6.47(1 \mathrm{H}, \mathrm{d}, 8.8) ; 6.55(2 \mathrm{H}, \mathrm{s}) ; 7.40(1 \mathrm{H}, \mathrm{dd}, 8.8$, 2.4); $8.20(1 \mathrm{H}, \mathrm{d}, 2.4) .{ }^{13} \mathrm{C}-\mathrm{NMR} \delta: 38.3(2)\left(\mathrm{CH}_{3}\right) ; 56.2(2)\left(\mathrm{CH}_{3}\right) ; 61.0\left(\mathrm{CH}_{3}\right) ; 105.2(\mathrm{CH}) ; 105.4(2)(\mathrm{CH})$; $111.6(\mathrm{C}) ; 111.8\left(\mathrm{CH}_{2}\right) ; 124.7(\mathrm{C}) ; 137.2(\mathrm{C}) ; 137.6(\mathrm{CH}) ; 146.5(\mathrm{C}) ; 147.0(\mathrm{CH}) ; 153.0(2)(\mathrm{C}) ; 158.3(\mathrm{C})$. IR (KBr): 1603; 1577; 1510; 1454; 1388; $1125 \mathrm{~cm}^{-1}$. Mp (Hex/EtOAc): 92-93 ${ }^{\circ} \mathrm{C}$. HRMS: calculated for $\mathrm{C}_{18} \mathrm{H}_{23} \mathrm{~N}_{2} \mathrm{O}_{3}[\mathrm{M}+\mathrm{H}]^{+}$: 315.1709; found: 315.1715 .

2-(Pyrrolidin-1-yl)-5-(1-(3,4,5-trimethoxyphenyl)vinyl)pyridine (3c). A solution of $176 \mathrm{mg}(0.51 \mathrm{mmol})$ of $1 \mathrm{c}$ in THF was added to a suspension of $623 \mathrm{mg}(1.54 \mathrm{mmol})$ of methyltriphenylphosphonium iodide and $1.0 \mathrm{~mL}(1.6 \mathrm{mmol})$ of $n \mathrm{BuLi}\left(1.6 \mathrm{M}\right.$ in hexane) in dry THF at $-40{ }^{\circ} \mathrm{C}$ to obtain, after column chromatography with Hex/EtOAc 1:1, $80 \mathrm{mg}(0.23 \mathrm{mmol}, 46 \%)$ of compound 3c. ${ }^{1} \mathrm{H}-\mathrm{NMR} \delta: 2.00(4 \mathrm{H}$, $\mathrm{m}) ; 3.47(4 \mathrm{H}, \mathrm{m}) ; 3.79(6 \mathrm{H}, \mathrm{s}) ; 3.85(3 \mathrm{H}, \mathrm{s}) ; 5.23(1 \mathrm{H}, \mathrm{s}) ; 5.31(1 \mathrm{H}, \mathrm{s}) ; 6.33(1 \mathrm{H}, \mathrm{d}, 8.8) ; 6.54(2 \mathrm{H}, \mathrm{s}) ; 7.41$ 
$(1 \mathrm{H}, \mathrm{dd}, 8.8,2.2) ; 8.18(1 \mathrm{H}, \mathrm{d}, 2.2) .{ }^{13} \mathrm{C}-\mathrm{NMR} \delta: 25.5(2)\left(\mathrm{CH}_{2}\right) ; 46.9(2)\left(\mathrm{CH}_{2}\right) ; 56.1$ (2) $\left(\mathrm{OCH}_{3}\right) ; 60.8$ $\left(\mathrm{OCH}_{3}\right) ; 105.5(2)(\mathrm{CH}) ; 106.0(\mathrm{CH}) ; 111.2\left(\mathrm{CH}_{2}\right) ; 124.3(\mathrm{C}) ; 137.1(\mathrm{CH}) ; 134.5(\mathrm{C}) ; 137.8(\mathrm{C}) ; 147.0(\mathrm{CH})$; 147.2 (C); 152.8 (2) (C); 156.3 (C). IR (KBr): 1600; 1506; 1235; 1126; $1006 \mathrm{~cm}^{-1}$. HRMS: calculated for $\mathrm{C}_{20} \mathrm{H}_{25} \mathrm{~N}_{2} \mathrm{O}_{3}[\mathrm{M}+\mathrm{H}]^{+}$: 341.1865; found 341.1870.

N,N-dimethyl-4-(1-(2,3,4-trimethoxyphenyl)vinyl)aniline (3d). A solution of $500 \mathrm{mg}$ (1.58 mmol) of $\mathbf{1 d}$ in THF was added to a suspension of $1.93 \mathrm{~g}(4.80 \mathrm{mmol})$ of methyltriphenylphosphonium iodide and $2.5 \mathrm{~mL}(4.0 \mathrm{mmol})$ of $n \mathrm{BuLi}\left(1.6 \mathrm{M}\right.$ in hexane) in dry THF at $-40{ }^{\circ} \mathrm{C}$ to obtain, after column chromatography with Hex/EtOAc 9:1, $349 \mathrm{mg}(1.11 \mathrm{mmol}, 70 \%)$ of compound 3d. ${ }^{1} \mathrm{H}-\mathrm{NMR} \delta: 2.95$ $(6 \mathrm{H}, \mathrm{s}) ; 3.59(3 \mathrm{H}, \mathrm{s}) ; 3.87(3 \mathrm{H}, \mathrm{s}) ; 3.89(3 \mathrm{H}, \mathrm{s}) ; 5.09(1 \mathrm{H}, \mathrm{d}, 1.6) ; 5.54(1 \mathrm{H}, \mathrm{d}, 1.6) ; 6.64(2 \mathrm{H}, \mathrm{d}, 8.8) ; 6.67$ $(1 \mathrm{H}, \mathrm{d}, 8.4) ; 6.92(1 \mathrm{H}, \mathrm{d}, 8.4) ; 7.19(2 \mathrm{H}, \mathrm{d}, 8.8) .{ }^{13} \mathrm{C}-\mathrm{NMR} \delta: 40.5(2)\left(\mathrm{CH}_{3}\right) ; 56.0\left(\mathrm{CH}_{3}\right) ; 60.8\left(\mathrm{CH}_{3}\right) ; 60.9$ $\left(\mathrm{CH}_{3}\right) ; 106.9(\mathrm{CH}) ; 111.8\left(\mathrm{CH}_{2}\right) ; 112.1(2)(\mathrm{CH}) ; 125.4(\mathrm{CH}) ; 127.6(2)(\mathrm{CH}) ; 129.8(\mathrm{C}) ; 129.9(\mathrm{C}) ; 142.4(\mathrm{C}) ;$ 146.5 (C); 150.1 (C); 151.8 (C); 153.3 (C). IR (KBr): $1602 ; 1521 \mathrm{~cm}^{-1}$. Mp (t-butylmethylether): $63-65^{\circ} \mathrm{C}$. HRMS: calculated for $\mathrm{C}_{19} \mathrm{H}_{24} \mathrm{NO}_{3}[\mathrm{M}+\mathrm{H}]^{+}$: 314.1756; found: 314.1748 .

4-(1-(2,5-Dimethoxyphenyl)vinyl)-N,N-dimethylaniline (3e). A solution of $500 \mathrm{mg}(1.75 \mathrm{mmol})$ of $1 \mathrm{e}$ in THF was added to a suspension of $2.12 \mathrm{~g}(4.80 \mathrm{mmol})$ of methyltriphenylphosphonium iodide and $2.7 \mathrm{~mL}$ ( $4.38 \mathrm{mmol})$ of $n \mathrm{BuLi}\left(1.6 \mathrm{M}\right.$ in hexane) in dry THF at $-40{ }^{\circ} \mathrm{C}$ to obtain, after column chromatography with Hex/EtOAc 6:4, $245 \mathrm{mg}(0.87 \mathrm{mmol}, 50 \%)$ of compound 3e. ${ }^{1} \mathrm{H}-\mathrm{NMR} \delta: 2.99(6 \mathrm{H}, \mathrm{s}) ; 3.68(3 \mathrm{H}, \mathrm{s})$; $3.82(3 \mathrm{H}, \mathrm{s}) ; 5.18(1 \mathrm{H}, \mathrm{s}) ; 5.70(1 \mathrm{H}, \mathrm{s}) ; 6.70(2 \mathrm{H}, \mathrm{d}, 9.0) ; 6.90(3 \mathrm{H}, \mathrm{s}) ; 7.28(2 \mathrm{H}, \mathrm{d}, 9.0) .{ }^{13} \mathrm{C}-\mathrm{NMR} \delta: 40.6$ (2) $\left(\mathrm{CH}_{3}\right) ; 55.8\left(\mathrm{CH}_{3}\right) ; 56.7\left(\mathrm{CH}_{3}\right) ; 111.7\left(\mathrm{CH}_{2}\right) ; 112.1(2)(\mathrm{CH}) ; 112.8(\mathrm{CH}) ; 113.2(\mathrm{CH}) ; 117.1(\mathrm{CH}) ; 127.3$ (2) (CH); 128.8 (C); 133.0 (C); 146.4 (C); 150.1 (C); 151.6 (C); 153.7 (C). IR (KBr): 1525, $1605 \mathrm{~cm}^{-1}$. Mp (t-butylmethylether): $68-70{ }^{\circ} \mathrm{C}$. HRMS: calculated for $\mathrm{C}_{18} \mathrm{H}_{22} \mathrm{NO}_{2}[\mathrm{M}+\mathrm{H}]^{+}$: 284.1651; found: 284.1645 .

N,N-Dimethyl-3-(1-(3,4,5-trimethoxyphenyl)vinyl)aniline (3f). A solution of $300 \mathrm{mg}$ (0.95 mmol) of $\mathbf{1 f}$ in THF was added to a suspension of $1.15 \mathrm{~g}(2.85 \mathrm{mmol})$ of methyltriphenylphosphonium iodide and $1.2 \mathrm{~mL}(1.9 \mathrm{mmol})$ of $n \mathrm{BuLi}\left(1.6 \mathrm{M}\right.$ in hexane) in dry THF at $-40{ }^{\circ} \mathrm{C}$ to obtain, after column chromatography with Hex/EtOAc 7:3, $280 \mathrm{mg}(0.89 \mathrm{mmol}, 94 \%)$ of compound $3 \mathrm{f} .{ }^{1} \mathrm{H}-\mathrm{NMR}\left(\mathrm{CD}_{3} \mathrm{OD}\right) \delta$ : $2.90(6 \mathrm{H}, \mathrm{s}) ; 3.75(6 \mathrm{H}, \mathrm{s}) ; 3.78(3 \mathrm{H}, \mathrm{s}) ; 5.38(1 \mathrm{H}, \mathrm{d}, 1.2) ; 5.41(1 \mathrm{H}, \mathrm{d}, 1.2) ; 6.61(2 \mathrm{H}, \mathrm{s}) ; 6.65(1 \mathrm{H}, \mathrm{d}, 8.0) ; 6.73$ $(1 \mathrm{H}, \mathrm{s}) ; 6.75(1 \mathrm{H}, \mathrm{dd}, 8.0) ; 7.16(1 \mathrm{H}, \mathrm{t}, 8.0) .{ }^{13} \mathrm{C}-\mathrm{NMR}\left(\mathrm{CD}_{3} \mathrm{OD}\right) \delta: 40.8(2)\left(\mathrm{CH}_{3}\right) ; 56.2(2)\left(\mathrm{CH}_{3}\right) ; 60.9$ $\left(\mathrm{CH}_{3}\right) ; 105.7(2)(\mathrm{CH}) ; 112.3(\mathrm{CH}) ; 112.8(\mathrm{CH}) ; 113.6\left(\mathrm{CH}_{2}\right) ; 117.3(\mathrm{CH}) ; 128.8(\mathrm{CH}) ; 137.5(\mathrm{C}) ; 137.7(\mathrm{C}) ;$ 142.1 (C); 150.5 (C); 150.8 (C); 152.8 (2) (C). IR (film): 1596; 1578; 1503; 1411; 1353; 1235; 1127; $898 \mathrm{~cm}^{-1}$. HRMS: calculated for $\mathrm{C}_{19} \mathrm{H}_{24} \mathrm{NO}_{3}[\mathrm{M}+\mathrm{H}]^{+}$: 314.1756; found: 314.1750

N,N-Dimethyl-4-(1-(3,4,5-trimethoxyphenyl)vinyl)pyridin-2-amine (3g). A solution of $141 \mathrm{mg}(0.44 \mathrm{mmol})$ of $1 \mathrm{~g}$ in THF was added to a suspension of $510 \mathrm{mg}(1.26 \mathrm{mmol})$ of methyltriphenylphosphonium iodide and $1.0 \mathrm{~mL}(1.6 \mathrm{mmol})$ of $n \mathrm{BuLi}\left(1.6 \mathrm{M}\right.$ in hexane) in dry THF at $-40{ }^{\circ} \mathrm{C}$ to obtain, after column chromatography with $\mathrm{CH}_{2} \mathrm{Cl}_{2} / \mathrm{EtOAc} 9: 1,102 \mathrm{mg}(0.32 \mathrm{mmol}, 73 \%)$ of compound $3 \mathrm{~g} .{ }^{1} \mathrm{H}-\mathrm{NMR}$ $\left(\mathrm{CD}_{3} \mathrm{OD}\right) \delta: 3.10(6 \mathrm{H}, \mathrm{s}) ; 3.82(6 \mathrm{H}, \mathrm{s}) ; 3.88(3 \mathrm{H}, \mathrm{s}) ; 5.51(1 \mathrm{H}, \mathrm{s}) ; 5.53(1 \mathrm{H}, \mathrm{s}) ; 6.49(1 \mathrm{H}, \mathrm{d}, 8.2) ; 6.52(1 \mathrm{H}, \mathrm{s})$; $6.53(2 \mathrm{H}, \mathrm{s}) ; 8.12(1 \mathrm{H}, \mathrm{d}, 8.2) .{ }^{13} \mathrm{C}-\mathrm{NMR}\left(\mathrm{CD}_{3} \mathrm{OD}\right) \delta: 37.1(2)\left(\mathrm{CH}_{3}\right) ; 55.0(2)\left(\mathrm{CH}_{3}\right) ; 59.5\left(\mathrm{CH}_{3}\right) ; 105.1(2)$ $(\mathrm{CH}) ; 110.9(\mathrm{CH}) ; 111.9(\mathrm{CH}) ; 114.9\left(\mathrm{CH}_{2}\right) ; 135.8(\mathrm{C}) ; 137.6(\mathrm{C}) ; 146.5(\mathrm{CH}) ; 148.6(\mathrm{C}) ; 150.3(\mathrm{C}) ; 152.6(2)$ (C); 159.3 (C). IR (film): 1594; 1541; 1502; 1409; 1234; $1127 \mathrm{~cm}^{-1}$. HRMS: calculated for $\mathrm{C}_{18} \mathrm{H}_{23} \mathrm{~N}_{2} \mathrm{O}_{3}$ $[\mathrm{M}+\mathrm{H}]^{+}:$315.1709; found: 315.1712 .

2-(Pyrrolidin-1-yl)-4-(1-(3,4,5-trimethoxyphenyl)vinyl)pyridine (3h). A solution of $360 \mathrm{mg}$ (1.05 mmol) of $1 \mathrm{~g}$ in THF was added to a suspension of $1.27 \mathrm{~g}(3.15 \mathrm{mmol})$ of methyltriphenylphosphonium iodide and $1.6 \mathrm{~mL}$ (2.6 mmol) of $n \mathrm{BuLi}\left(1.6 \mathrm{M}\right.$ in hexane) in dry THF at $-40{ }^{\circ} \mathrm{C}$ to obtain, after column chromatography with Hex/EtOAc 8:2, $295 \mathrm{mg}(0.87 \mathrm{mmol}, 83 \%)$ of compound $3 \mathrm{~h} .{ }^{1} \mathrm{H}-\mathrm{NMR} \delta: 1.98(4 \mathrm{H}$, $\mathrm{m}) ; 3.43(4 \mathrm{H}, \mathrm{m}) ; 3.80(6 \mathrm{H}, \mathrm{s}) ; 3.86(3 \mathrm{H}, \mathrm{s}) ; 5.47(1 \mathrm{H}, \mathrm{s}) ; 5.50(1 \mathrm{H}, \mathrm{s}) ; 6.31(2 \mathrm{H}, \mathrm{s}) ; 6.46(1 \mathrm{H}, \mathrm{d}, 5.0) ; 6.53$ $(1 \mathrm{H}, \mathrm{s}) ; 8.10(1 \mathrm{H}, \mathrm{d}, 5.0) .{ }^{13} \mathrm{C}-\mathrm{NMR}$ $: 25.5(2)\left(\mathrm{CH}_{2}\right) ; 46.8(2)\left(\mathrm{CH}_{2}\right) ; 56.1(2)\left(\mathrm{CH}_{3}\right) ; 60.9\left(\mathrm{CH}_{3}\right) ; 105.5(2)$ $(\mathrm{CH}) ; 105.8(\mathrm{CH}) ; 111.1(\mathrm{CH}) ; 115.3\left(\mathrm{CH}_{2}\right) ; 135.9(\mathrm{C}) ; 137.9(\mathrm{C}) ; 147.9(\mathrm{C}) ; 149(\mathrm{CH}) ; 149.7(\mathrm{C}) ; 152.9$ (2) 
(C); 157.6 (C). IR (film): 1593; 1535; 1492; 1454; 1236; $1126 \mathrm{~cm}^{-1}$. HRMS: calculated for $\mathrm{C}_{20} \mathrm{H}_{25} \mathrm{~N}_{2} \mathrm{O}_{3}$ $[\mathrm{M}+\mathrm{H}]^{+}$: 341.1865 ; found: 341.1862 .

4.1.5. General Procedure to Obtain Dihydro Derivatives by Reduction of Isocombretastatins $(\mathbf{4 d}, \mathbf{4 e}, \mathbf{4 f})$

Catalytic amounts of $\mathrm{Pd} / \mathrm{C}$ were added over a $0.01-0.02 \mathrm{M}$ solution of the isocombretastatins in ethanol. After $24 \mathrm{~h}$ stirring at room temperature and under hydrogen atmosphere, the residue was filtered over silica gel and concentrated under vacuum.

N,N-Dimethyl-4-(1-(2,3,4-trimethoxyphenyl)ethyl)aniline (4d). Ten $\mathrm{mg}$ of $\mathrm{Pd} / \mathrm{C}$ were added to a solution of $84 \mathrm{mg}(0.30 \mathrm{mmol})$ of $3 \mathbf{d}$ in EtOH under hydrogen atmosphere to obtain, after column chromatography with Hex/EtOAc 95:5, $56 \mathrm{mg}(0.20 \mathrm{mmol} ; 67 \%)$ of $4 \mathrm{~d} .{ }^{1} \mathrm{H}-\mathrm{NMR} \delta: 1.55(3 \mathrm{H}, \mathrm{d}, 7.3) ; 2.91(6 \mathrm{H}, \mathrm{s}) ; 3.70(3 \mathrm{H}$, s); $3.84(3 \mathrm{H}, \mathrm{s}) ; 3.87(3 \mathrm{H}, \mathrm{s}) ; 4.40(1 \mathrm{H}, \mathrm{q}, 7.3) ; 6.63(1 \mathrm{H}, \mathrm{d}, 8.6) ; 6.71(2 \mathrm{H}, \mathrm{d}, 8.6) ; 6.88(1 \mathrm{H}, \mathrm{d}, 8.6) ; 7.12$ $(2 \mathrm{H}, \mathrm{d}, 8.6) .{ }^{13} \mathrm{C}-\mathrm{NMR}$ 8: $21.8(\mathrm{CH}) ; 36.7\left(\mathrm{CH}_{3}\right) ; 40.8(\mathrm{CH}) ; 55.9(\mathrm{CH}) ; 60.6(\mathrm{CH}) ; 60.8(\mathrm{CH}) ; 107.0\left(\mathrm{CH}_{3}\right)$; $112.8\left(\mathrm{CH}_{3}\right) ; 121.7\left(\mathrm{CH}_{3}\right) ; 128.1(2)\left(\mathrm{CH}_{3}\right) ; 133.3(\mathrm{C}) ; 135.2(\mathrm{C}) ; 142.2(\mathrm{C}) ; 148.7(\mathrm{C}) ; 151.4(\mathrm{C}) ; 151.7(\mathrm{C})$. IR (film): 1519; $1610 \mathrm{~cm}^{-1}$. HRMS: calculated for $\mathrm{C}_{19} \mathrm{H}_{26} \mathrm{NO}_{3}[\mathrm{M}+\mathrm{H}]^{+}$: 316.1913; found: 316.1915.

4-(1-(2,5-Dimethoxyphenyl)ethyl)-N,N-dimethylaniline (4e). Ten $\mathrm{mg}$ of $\mathrm{Pd} / \mathrm{C}$ were added to a solution of $63.5 \mathrm{mg}(0.22 \mathrm{mmol})$ of $3 \mathbf{e}$ in EtOH under hydrogen atmosphere to obtain, after column chromatography with Hex/EtOAc 95:5, $44 \mathrm{mg}(0.15 \mathrm{mmol} ; 68 \%)$ of 4 e. ${ }^{1} \mathrm{H}-\mathrm{NMR} \delta: 1.55(3 \mathrm{H}, \mathrm{d}, 7.2) ; 2.91(6 \mathrm{H}, \mathrm{s}) ; 3.73$ $(3 \mathrm{H}, \mathrm{s}) ; 3.75(3 \mathrm{H}, \mathrm{s}) ; 4.49(1 \mathrm{H}, \mathrm{q}, 7.2) ; 6.56-6.79(5 \mathrm{H}, \mathrm{m}) ; 7.14(2 \mathrm{H}, \mathrm{d}, 8.6) .{ }^{13} \mathrm{C}-\mathrm{NMR}$ 8: $20.9\left(\mathrm{CH}_{3}\right) ; 36.5$ $(\mathrm{CH}) ; 40.9\left(\mathrm{CH}_{3}\right) ; 55.5\left(\mathrm{CH}_{3}\right) ; 56.2\left(\mathrm{CH}_{3}\right) ; 77.0(\mathrm{c}) ; 110.2(\mathrm{CH}) ; 111.6(\mathrm{CH}) ; 112.9(\mathrm{CH}) ; 114.6(\mathrm{CH}) ; 128.2$ (2) (CH); 137.2 (C); 148.7 (C); 151.2 (C); 153.6 (C). IR (film): 1517; $1613 \mathrm{~cm}^{-1}$. HRMS: calculated for $\mathrm{C}_{18} \mathrm{H}_{24} \mathrm{NO}_{2}[\mathrm{M}+\mathrm{H}]^{+}$: 286.1807; found: 286.1816 .

N,N-Dimethyl-3-(1-(3,4,5-trimethoxyphenyl)ethyl)aniline (4f). Ten $\mathrm{mg}$ of $\mathrm{Pd} / \mathrm{C}$ were added to a solution of $50 \mathrm{mg}(0.16 \mathrm{mmol})$ of $3 \mathrm{f}$ in EtOH under hydrogen atmosphere to obtain $47 \mathrm{mg}(0.15 \mathrm{mmol} ; 94 \%)$ of $4 \mathrm{f}$. ${ }^{1} \mathrm{H}-\mathrm{NMR}$ 8: $1.63(3 \mathrm{H}, \mathrm{d}, 7.5) ; 2.93(6 \mathrm{H}, \mathrm{s}) ; 3.99(9 \mathrm{H}, \mathrm{s}) ; 4.10(1 \mathrm{H}, \mathrm{q}, 7.5) ; 6.48(2 \mathrm{H}, \mathrm{s}) ; 6.60(1 \mathrm{H}, \mathrm{d}, 6.5)$; $6.62(1 \mathrm{H}, \mathrm{d}, 6.5) ; 6.66(1 \mathrm{H}, \mathrm{bs}) ; 7.22(1 \mathrm{H}, \mathrm{t}, 6.5) .{ }^{13} \mathrm{C}-\mathrm{NMR} \delta: 22.2\left(\mathrm{CH}_{3}\right) ; 41.1(2)\left(\mathrm{CH}_{3}\right) ; 45.5(\mathrm{CH}) ; 56.1$ (2) $\left(\mathrm{CH}_{3}\right) ; 60.9\left(\mathrm{CH}_{3}\right) ; 104.7(2)(\mathrm{CH}) ; 111.1(\mathrm{CH}) ; 112.7(\mathrm{CH}) ; 129.2(2)(\mathrm{CH}) ; 136.2(\mathrm{C}) ; 142.2(\mathrm{C}) ; 147.2$ (C); 150.2 (C); 153.0 (2) (C). IR (film): 1589; 1499; 1458; 1327; 1233; $1126 \mathrm{~cm}^{-1}$. HRMS: calculated for $\mathrm{C}_{19} \mathrm{H}_{26} \mathrm{NO}_{3}[\mathrm{M}+\mathrm{H}]^{+}$: 316.1913; found: 316.1909 .

\subsubsection{General Procedure to Obtain Combretastatins by Wittig Reactions $(\mathbf{8} \mathbf{a}-\mathbf{c}$ and $\mathbf{8 g}-\mathbf{i})$}

0.75 to $1.10 \mathrm{mmol}$ per mmol of $n \mathrm{BuLi}(1.6 \mathrm{M}$ in hexane) were added to a $0.08 \mathrm{M}$ suspension of triphenyl (3,4,5-trimethoxybenzyl)phosphonium bromide in dry THF at $-78^{\circ} \mathrm{C}$ under inert atmosphere. After one hour stirring, 0.25 to $0.90 \mathrm{mmol}$ of the corresponding aromatic aldehyde per mmol of the phosphonium salt were added and reaction was allowed to reach room temperature. After $24 \mathrm{~h}$, the reaction was poured onto ice and extracted with $\mathrm{CH}_{2} \mathrm{Cl}_{2}$. Organic layers were washed with brine, dried over sodium sulphate and concentrated under vacuum. The residue was purified by column chromatography on silica gel.

N,N-dimethyl-4-(3,4,5-trimethoxystyryl)aniline (8a) [15]. A solution of $1.00 \mathrm{~g}(6.70 \mathrm{mmol})$ of $p$-dimethylaminebenzaldehyde in THF was added to a suspension of $4.20 \mathrm{~g}(8.04 \mathrm{mmol})$ of triphenyl(3,4,5-trimethoxybenzyl)phosphonium bromide and $6.10 \mathrm{~mL}(9.65 \mathrm{mmol})$ of $n \mathrm{BuLi}(1.6 \mathrm{M}$ in hexane) in dry THF at $-78{ }^{\circ} \mathrm{C}$ to obtain, after column chromatography with Hex/EtOAc 7:3, $290 \mathrm{mg}$ $(0.92 \mathrm{mmol}, 14 \%)$ of isomer (Z)-8a, $113 \mathrm{mg}(0.36 \mathrm{mmol}, 5 \%)$ of isomer $(E)-8 \mathbf{b}$ and $1.20 \mathrm{~g}(3.83 \mathrm{mmol}$, 57\%) of a 1:1 Z/E mixture. (Z)-8a: ${ }^{1} \mathrm{H}-\mathrm{NMR} \delta: 2.93(6 \mathrm{H}, \mathrm{s}) ; 3.71(6 \mathrm{H}, \mathrm{s}) ; 3.85(3 \mathrm{H}, \mathrm{s}) ; 6.32(1 \mathrm{H}, \mathrm{d}, 12.2)$; $6.46(1 \mathrm{H}, \mathrm{d}, 12.2) ; 6.57(2 \mathrm{H}, \mathrm{s}) ; 6.60(2 \mathrm{H}, \mathrm{d} ; 8.6) ; 7.20(2 \mathrm{H}, \mathrm{d}, 8.6) .{ }^{13} \mathrm{C}-\mathrm{NMR} \delta: 40.5(2)\left(\mathrm{CH}_{3}\right) ; 55.9(2)$ $\left(\mathrm{CH}_{3}\right) ; 60.9\left(\mathrm{CH}_{3}\right) ; 105.8(2)(\mathrm{CH}) ; 112.0(2)(\mathrm{CH}) ; 125.1(\mathrm{C}) ; 126.8(\mathrm{CH}) ; 130.1(3)(\mathrm{CH}) ; 133.6(\mathrm{C}) ; 136.7$ (C); 149.7 (C); 152.9 (2) (C). IR (film): 1606; 1585; 1516; 1236; 1126; $767 \mathrm{~cm}^{-1}$. HRMS: calculated for 
$\mathrm{C}_{19} \mathrm{H}_{24} \mathrm{NO}_{3}[\mathrm{M}+\mathrm{H}]^{+}:$314.1751; found: 314.1758. (E)-8a: ${ }^{1} \mathrm{H}-\mathrm{NMR} \delta: 2.99(6 \mathrm{H}, \mathrm{s}) ; 3.87(3 \mathrm{H}, \mathrm{s}) ; 3.92(6 \mathrm{H}$, s); $6.74(2 \mathrm{H}, \mathrm{s}) ; 6.76(2 \mathrm{H}, \mathrm{d}, 8.8) ; 6.82(1 \mathrm{H}, \mathrm{d}, 15.4) ; 6.96(1 \mathrm{H}, \mathrm{d}, 15.4) ; 7.40(2 \mathrm{H}, \mathrm{d}, 8.8) .{ }^{13} \mathrm{C}-\mathrm{NMR} \delta: 40.6$ (2) $\left(\mathrm{CH}_{3}\right) ; 56.1(2)\left(\mathrm{CH}_{3}\right) ; 61.0\left(\mathrm{CH}_{3}\right) ; 103.0(2)(\mathrm{CH}) ; 112.6(2)(\mathrm{CH}) ; 124.4(\mathrm{CH}) ; 125.8(\mathrm{C}) ; 127.6(2)(\mathrm{CH})$; 128.4 (CH); 134.0 (C); 137.2 (C); 150.0 (C); 153.4 (2) (C). IR (film): 1606; 1585; 1516; 1236; 1126; $767 \mathrm{~cm}^{-1}$. Mp (diethyl ether): $94-95^{\circ} \mathrm{C}$. HRMS: calculated for $\mathrm{C}_{19} \mathrm{H}_{24} \mathrm{NO}_{3}[\mathrm{M}+\mathrm{H}]^{+}$: 314.1756; found: 314.1760 .

$\mathrm{N}, \mathrm{N}$-dimethyl-5-(3,4,5-trimethoxystyryl)pyridin-2-amine (8b). A solution of $230 \mathrm{mg}(1.53 \mathrm{mmol})$ of 6-(dimethylamino)nicotinaldehyde in THF was added to a suspension of $1.30 \mathrm{~g}$ (2.14 mmol) of triphenyl(3,4,5-trimethoxybenzyl)phosphonium bromide and $1.5 \mathrm{~mL}(2.10 \mathrm{mmol})$ of $n \mathrm{BuLi}(1.6 \mathrm{M}$ in hexane) in dry THF at $-40{ }^{\circ} \mathrm{C}$ to obtain, after column chromatography with Hex/EtOAc 1:1, $65 \mathrm{mg}$ $(0.21 \mathrm{mmol}, 14 \%)$ of isomer (Z)-8b, and $213 \mathrm{mg}(0.68 \mathrm{mmol}, 44 \%)$ of a 1:1 Z/E mixture. (Z)-8b: ${ }^{1} \mathrm{H}-\mathrm{NMR}$ 8: $3.05(6 \mathrm{H}, \mathrm{s}) ; 3.72(6 \mathrm{H}, \mathrm{s}) ; 3.83(3 \mathrm{H}, \mathrm{s}) ; 6.32(1 \mathrm{H}, \mathrm{d}, 8.8) ; 6.38(2 \mathrm{H}, \mathrm{s}) ; 6.51(2 \mathrm{H}, \mathrm{s}) ; 7.38(1 \mathrm{H}, \mathrm{dd}, 8.8,2.2)$; $8.09(1 \mathrm{H}, \mathrm{d}, 2.2) .{ }^{13} \mathrm{C}-\mathrm{NMR}$ 8: $38.1(2)\left(\mathrm{CH}_{3}\right) .56 .0(2)\left(\mathrm{CH}_{3}\right) .60 .8\left(\mathrm{CH}_{3}\right) .104 .7(\mathrm{CH}) .105 .7(2)(\mathrm{CH})$. 109.5 (C). 120.4 (C). 126.9 (CH). $127.8(\mathrm{CH}) .133 .2(\mathrm{C}) .133 .6$ (C). $137.2(\mathrm{CH}) .148 .9(\mathrm{CH}) .153 .3(2)(\mathrm{C})$. 158.5 (C). IR (film): 1606; 1600; 1508; 1457; 1389; 1236; $1126 \mathrm{~cm}^{-1}$. HRMS: calculated for $\mathrm{C}_{18} \mathrm{H}_{23} \mathrm{~N}_{2} \mathrm{O}_{3}$ $[\mathrm{M}+\mathrm{H}]^{+}$: 315.1709; found: 315.1708. (E)-8b: ${ }^{1} \mathrm{H}-\mathrm{NMR} \delta: 3.11(6 \mathrm{H}, \mathrm{s}) ; 3.86(3 \mathrm{H}, \mathrm{s}) ; 3.92(6 \mathrm{H}, \mathrm{s}) ; 6.52$ $(1 \mathrm{H}, \mathrm{d}, 8.8) ; 6.69(2 \mathrm{H}, \mathrm{s}) ; 6.80(1 \mathrm{H}, \mathrm{d}, 16.4) ; 6.89(1 \mathrm{H}, \mathrm{d}, 16.4) ; 7.67(1 \mathrm{H}, \mathrm{dd}, 8.8,2.2) ; 8.22(1 \mathrm{H}, \mathrm{d}, 2.2)$. ${ }^{13} \mathrm{C}-\mathrm{NMR}$ 8: $38.5(2)\left(\mathrm{CH}_{3}\right) ; 56.4(2)\left(\mathrm{CH}_{3}\right) ; 61.2\left(\mathrm{CH}_{3}\right) ; 103.2(2)(\mathrm{CH}) ; 106.2(\mathrm{CH}) ; 121.3(\mathrm{C}) ; 125.5(\mathrm{CH})$; $128.1(\mathrm{CH}) ; 133.8$ (C); $134.1(\mathrm{CH}) ; 137.6$ (CH); 147.5 (C); 153.6 (2) (C); 158.8 (C). IR (film): 1606; 1585; $1516 ; 1236 ; 1126 ; 767 \mathrm{~cm}^{-1}$.

2-(Pyrrolidin-1-yl)-5-(3,4,5-trimethoxystyryl)pyridine (8c). A solution of $57 \mathrm{mg}(0.32 \mathrm{mmol})$ of 6-(pyrrolidin-1-yl)nicotinaldehyde in THF was added to a suspension of $156 \mathrm{mg}(0.27 \mathrm{mmol})$ of triphenyl(3,4,5-trimethoxybenzyl)phosphonium bromide and $0.2 \mathrm{~mL}(0.12 \mathrm{mmol})$ of $n \mathrm{BuLi}(1.6 \mathrm{M}$ in hexane) in dry THF at $-40{ }^{\circ} \mathrm{C}$ to obtain, after column chromatography with Hex/EtOAc 1:1, $40 \mathrm{mg}$ $(0.12 \mathrm{mmol}, 38 \%)$ of a 1:1 Z/E mixture of compound 8c. (Z)-8c: ${ }^{1} \mathrm{H}-\mathrm{NMR} \delta: 2.04(4 \mathrm{H}, \mathrm{m}) ; 3.50(4 \mathrm{H}, \mathrm{m})$; $3.78(6 \mathrm{H}, \mathrm{s}) ; 3.92(3 \mathrm{H}, \mathrm{s}) ; 6.23(1 \mathrm{H}, \mathrm{d}, 8.8) ; 6.33(1 \mathrm{H}, \mathrm{d}, 12.0) ; 6.43(1 \mathrm{H}, \mathrm{d}, 12.0) ; 6.49(2 \mathrm{H}, \mathrm{s}) ; 7.40(1 \mathrm{H}$, $\mathrm{dd}, 8.8,2.2) ; 8.11(1 \mathrm{H}, \mathrm{d}, 2.2)$. (E)-8c: $2.02(4 \mathrm{H}, \mathrm{m}) ; 3.50(4 \mathrm{H}, \mathrm{m}) ; 3.85(6 \mathrm{H}, \mathrm{s}) ; 3.93(3 \mathrm{H}, \mathrm{s}) ; 6.36(1 \mathrm{H}, \mathrm{s})$; $6.70(2 \mathrm{H}, \mathrm{s}) ; 6.71(1 \mathrm{H}, \mathrm{d}, 4.4) ; 6.84(1 \mathrm{H}, \mathrm{d}, 2.2) ; 6.94(1 \mathrm{H}, \mathrm{s}) ; 8.22(1 \mathrm{H}, \mathrm{d}, 2.2)$. HRMS: calculated for $\mathrm{C}_{20} \mathrm{H}_{25} \mathrm{~N}_{2} \mathrm{O}_{3}[\mathrm{M}+\mathrm{H}]^{+}$: 341.1865; found: 341.1868 .

2-(Pyrrolidin-1-yl)-4-(3,4,5-trimethoxystyryl)pyridine (8h). A solution of $400 \mathrm{mg}(2.27 \mathrm{mmol})$ of 6-(dimethylamino)nicotinaldehyde in THF was added to a suspension of $1.66 \mathrm{~g}(3.18 \mathrm{mmol})$ of triphenyl(3,4,5-trimethoxybenzyl)phosphonium bromide and $2.0 \mathrm{~mL}(3.18 \mathrm{mmol})$ of $n \mathrm{BuLi}(1.6 \mathrm{M}$ in hexane) in dry THF at $-40{ }^{\circ} \mathrm{C}$ to obtain, after column chromatography with Hex/EtOAc $6: 4,123 \mathrm{mg}$ $(0.23 \mathrm{mmol}, 16 \%)$ of isomer (Z)-8h, and $181 \mathrm{mg}(0.53 \mathrm{mmol}, 17 \%)$ of a 1:1 Z/E mixture. (Z)-8h: ${ }^{1} \mathrm{H}-\mathrm{NMR}$

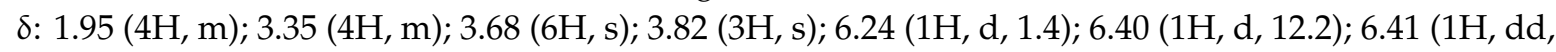
5.2, 1.4); $6.50(2 \mathrm{H}, \mathrm{s}) ; 6.54(1 \mathrm{H}, \mathrm{d}, 12.2) ; 8.02(1 \mathrm{H}, \mathrm{d}, 5.2) .{ }^{13} \mathrm{C}-\mathrm{NMR} \delta: 25.5(2)\left(\mathrm{CH}_{2}\right) ; 46.6(2)\left(\mathrm{CH}_{2}\right) ; 56.0$ (2) $\left(\mathrm{CH}_{3}\right) ; 60.9\left(\mathrm{CH}_{3}\right) ; 106.1(2)(\mathrm{CH}) ; 106.1(\mathrm{CH}) ; 111.3(\mathrm{CH}) ; 128.5(\mathrm{CH}) ; 132.2(\mathrm{C}) ; 132.3(\mathrm{CH}) ; 137.5(\mathrm{C})$ 145.9 (C); 147.9 (2) (C); 152.9 (CH); 157.6 (C). IR (film): 1650; 1598; 1538; 1329; 1229; $1127 \mathrm{~cm}^{-1}$. HRMS: calculated for $\mathrm{C}_{20} \mathrm{H}_{25} \mathrm{~N}_{2} \mathrm{O}_{3}[\mathrm{M}+\mathrm{H}]^{+}: 341.1865$; found: 341.1868. (E)-8h: ${ }^{1} \mathrm{H}-\mathrm{NMR} \delta: 1.98(4 \mathrm{H}, \mathrm{m}) ; 3.45$ $(4 \mathrm{H}, \mathrm{m}) ; 3.80(6 \mathrm{H}, \mathrm{s}) ; 3.84(3 \mathrm{H}, \mathrm{s}) ; 6.48(1 \mathrm{H}, \mathrm{s}) ; 6.66(1 \mathrm{H}, \mathrm{d}, 5.4) ; 6.88(1 \mathrm{H}, \mathrm{d}, 16.1) ; 6.72(2 \mathrm{H}, \mathrm{s}) ; 7.08(1 \mathrm{H}$, d, 16.1); $8.07(1 \mathrm{H}, \mathrm{d}, 5.4) .{ }^{13} \mathrm{C}-\mathrm{NMR}$ 8: $25.6(2)\left(\mathrm{CH}_{2}\right) ; 46.8(2)\left(\mathrm{CH}_{2}\right) ; 56.1(2)\left(\mathrm{CH}_{3}\right) ; 60.9\left(\mathrm{CH}_{3}\right) ; 104.0(2)$ $(\mathrm{CH}) ; 104.5(\mathrm{CH}) ; 106.2(\mathrm{CH}) ; 126.6(\mathrm{C}) ; 126.7(\mathrm{CH}) ; 131.8(\mathrm{C}) ; 132.0(\mathrm{CH}) ; 137.5(\mathrm{CH}) 145.6(\mathrm{C}) ; 152.8(2)$ (C); 155.2 (C). IR (film): 1650; 1598; 1538; 1329; 1229; $1127 \mathrm{~cm}^{-1}$.

1-(4-(3,4,5-Trimethoxystyryl)phenyl)pyrrolidine (8i). A solution of $2.00 \mathrm{~g}$ (11.4 mmol) of 4-(pyrrolidin-1-yl) benzaldehyde in THF was added to a suspension of $7.10 \mathrm{~g}(13.70 \mathrm{mmol})$ of triphenyl (3,4,5-trimethoxybenzyl)phosphonium bromide and $9.8 \mathrm{~mL}$ (13.70 mmol) of $n \mathrm{BuLi}(1.6 \mathrm{M}$ in hexane) in dry THF at $-40^{\circ} \mathrm{C}$ to obtain, after column chromatography with Hex/EtOAc 7:3, $1.83 \mathrm{~g}(5.40 \mathrm{mmol}, 47 \%)$ of isomer (Z)-8i, and $1.20 \mathrm{~g}(0.53 \mathrm{mmol}, 31 \%)$ of isomer $(E)-8 \mathbf{i}$. (Z)-8i: ${ }^{1} \mathrm{H}-\mathrm{NMR} \delta: 1.99(4 \mathrm{H}, \mathrm{m}) ; 3.26(4 \mathrm{H}, \mathrm{m}$, 
$\left.\mathrm{NCH}_{2}\right) ; 3.73\left(6 \mathrm{H}, \mathrm{s}, \mathrm{OCH}_{3}\right) ; 3.86\left(3 \mathrm{H}, \mathrm{s}, \mathrm{OCH}_{3}\right) ; 6.30(1 \mathrm{H}, \mathrm{d} ; 12) ; 6,41(2 \mathrm{H}, \mathrm{d} ; 8.2) ; 6.45(1 \mathrm{H}, \mathrm{d}, 12) ; 6.62(2 \mathrm{H}, \mathrm{s}) ;$ $7.21(2 \mathrm{H}, \mathrm{d}, 8.2) .{ }^{13} \mathrm{C}-\mathrm{NMR} \delta: 25.5(2)\left(\mathrm{CH}_{2}\right) ; 47.6(2)\left(\mathrm{CH}_{2}\right) ; 56.0(2)\left(\mathrm{OCH}_{3}\right) ; 60.9\left(\mathrm{OCH}_{3}\right) ; 105.8(2)(\mathrm{CH})$; 111.2 (2) (CH); $124.0(\mathrm{C}) ; 126.0(\mathrm{CH}) ; 130.3(2)(\mathrm{CH}) ; 130.4(\mathrm{CH}) ; 133.9$ (C); 136.7 (C); 147.1 (C); 153.0 (2) (C). IR (film): 1604; 1237; 1126; $772 \mathrm{~cm}^{-1}$. HRMS: calculated for $\mathrm{C}_{21} \mathrm{H}_{26} \mathrm{NO}_{3}[\mathrm{M}+\mathrm{H}]^{+}$: 340.1913; found: 341.1902. (E)-8i: ${ }^{1} \mathrm{H}-\mathrm{NMR} \delta: 2.00(4 \mathrm{H}, \mathrm{m}) ; 3.31\left(4 \mathrm{H}, \mathrm{m}, \mathrm{NCH}_{2}\right) ; 3.87\left(3 \mathrm{H}, \mathrm{s}, \mathrm{OCH}_{3}\right) ; 3.91\left(6 \mathrm{H}, \mathrm{s}, \mathrm{OCH}_{3}\right)$; $6.56(2 \mathrm{H}, \mathrm{d}, 8.6) ; 6.70(2 \mathrm{H}, \mathrm{s}) ; 6.80(1 \mathrm{H}, \mathrm{d}, 16.1) ; 6.98(1 \mathrm{H}, \mathrm{d}, 16.1) ; 7.40(2 \mathrm{H}, \mathrm{d}, 8.6) .{ }^{13} \mathrm{C}-\mathrm{NMR}$ 8: $25.5(2)$ $\left(\mathrm{CH}_{2}\right) ; 47.7(2)\left(\mathrm{CH}_{2}\right) ; 56.1(2)\left(\mathrm{OCH}_{3}\right) ; 61.0\left(\mathrm{OCH}_{3}\right) ; 102.9(2)(\mathrm{CH}) ; 111.9(2)(\mathrm{CH}) ; 123.6(\mathrm{CH}) ; 124.7$ (C); 127.7 (2) (CH); 128.7 (CH); 134.2 (C); 137.1 (C); 147.5 (C); 153.4 (2) (C). IR (film): 1585, 1233, 1126, $818 \mathrm{~cm}^{-1}$. Mp (EtOAc): $118-119^{\circ} \mathrm{C}$.

\subsubsection{General Procedure to Obtain the Ammonium Salt Derivatives (5a, 5d, 5e, 6a, 7a, 7d, 9a, 9b and 9i)}

3.0-10.0 mmol per mmol of iodomethane were added to a $0.05 \mathrm{M}$ solution of the corresponding amino derivatives in dry acetone and the reaction was refluxed in a sealed tube for $24 \mathrm{~h}$. After cooling, the precipitate was filtered off and washed with ether.

N,N,N-Trimethyl-4-(3,4,5-trimethoxybenzoyl)benzenaminium iodide (5a). $200 \mathrm{mg}(0.63 \mathrm{mmol})$ of diarylketone 1a and $0.237 \mathrm{~mL}(3.81 \mathrm{mmol})$ of iodomethane led to $130 \mathrm{mg}(0.39 \mathrm{mmol}, 62 \%)$ of $5 \mathrm{a} .{ }^{1} \mathrm{H}-\mathrm{NMR}\left(\mathrm{CD}_{3} \mathrm{OD}\right) \delta$ : $3.68(9 \mathrm{H}, \mathrm{s}) ; 3.75(6 \mathrm{H}, \mathrm{s}) ; 3.77(3 \mathrm{H}, \mathrm{s}) ; 6.99(2 \mathrm{H}, \mathrm{s}) ; 7.88(2 \mathrm{H}, \mathrm{d}, 6.8) ; 8.01(2 \mathrm{H}, \mathrm{d}, 6.8) .{ }^{13} \mathrm{C}-\mathrm{NMR}\left(\mathrm{CD}_{3} \mathrm{OD}\right) \delta$ : 56.9 (3) $\left(\mathrm{CH}_{3}\right) ; 57.3(2)\left(\mathrm{CH}_{3}\right) ; 64.5\left(\mathrm{CH}_{3}\right) ; 109.1(2)(\mathrm{CH}) ; 121.5(2)(\mathrm{CH}) ; 132.7(2)(\mathrm{CH}) ; 141.0(\mathrm{C}) ; 147.8(\mathrm{C})$; 150.8 (C); 153.8 (C); 154.5 (2) (C); 190.0 (C). IR (KBr): 3002; 1661; 1582; 1332; $1125 \mathrm{~cm}^{-1}$. HRMS: calculated for $\mathrm{C}_{19} \mathrm{H}_{24} \mathrm{NO}_{4}[\mathrm{M}]^{+}$: 330.1700; found: 330.1690 .

N,N,N-Trimethyl-4-(2,3,4-trimethoxybenzoyl)benzenaminium iodide (5d). $250 \mathrm{mg}(0.79 \mathrm{mmol})$ of diarylketone $1 \mathrm{~d}$ and $0.495 \mathrm{~mL}$ (7.90 mmol) of iodomethane led to $180 \mathrm{mg}(0.39 \mathrm{mmol}, 69 \%)$ of $5 \mathrm{~d}$, after crystallization in methanol. ${ }^{1} \mathrm{H}-\mathrm{NMR}$ (Pyridine) $\delta: 3.35(3 \mathrm{H}, \mathrm{s}) ; 3.40(3 \mathrm{H}, \mathrm{s}) ; 3.45(3 \mathrm{H}, \mathrm{s}) ; 3.74(9 \mathrm{H}, \mathrm{s}) ; 6.47(1 \mathrm{H}, \mathrm{d}, 8.8)$; $7.02(1 \mathrm{H}, \mathrm{d}, 8.8) ; 7.70(2 \mathrm{H}, \mathrm{d}, 8.4) ; 7.72(2 \mathrm{H}, \mathrm{d}, 8.4) .{ }^{13} \mathrm{C}-\mathrm{NMR}$ (Pyridine) $\delta: 54.8\left(\mathrm{CH}_{3}\right) ; 56.8(3)\left(\mathrm{CH}_{3}\right) ; 59.4$ $\left(\mathrm{CH}_{3}\right) ; 60.6\left(\mathrm{CH}_{3}\right) ; 106.6(\mathrm{CH}) ; 119.6(2)(\mathrm{CH}) ; 124.1(\mathrm{CH}) ; 124.6(\mathrm{C}) ; 130.2(2)(\mathrm{CH}) ; 139.4(\mathrm{C}) ; 141.0(\mathrm{C}) ;$ 148.7 (C); 151.9 (C); 156.2 (C); 192.2 (C). IR (KBr): 1648; 1592; 1461; 1412; 1296; $1094 \mathrm{~cm}^{-1}$. Mp (methanol): 172-173 ${ }^{\circ} \mathrm{C}$. HRMS: calculated for $\mathrm{C}_{19} \mathrm{H}_{24} \mathrm{NO}_{4}[\mathrm{M}]^{+}$: 330.1700; found: 330.1705 .

4-(2,5-Dimethoxybenzoyl)-N,N,N-trimethylbenzenaminium iodide (5e). $260 \mathrm{mg}(0.91 \mathrm{mmol})$ of diarylketone 1e and $0.170 \mathrm{~mL}(2.71 \mathrm{mmol})$ of iodomethane led to $135 \mathrm{mg}(0.47 \mathrm{mmol}, 52 \%)$ of $5 \mathbf{e}$, after crystallization in methanol. ${ }^{1} \mathrm{H}-\mathrm{NMR}\left(\mathrm{DMSO}-d_{6}\right) \delta: 3.60(3 \mathrm{H}, \mathrm{s}) ; 3.63(9 \mathrm{H}, \mathrm{s}) ; 3.73(3 \mathrm{H}, \mathrm{s}) ; 6.93(1 \mathrm{H}, \mathrm{t}, 1.8) ; 7.15(2 \mathrm{H}$, $\mathrm{d}, 1.8) ; 7.84(2 \mathrm{H}, \mathrm{d}, 9.0) ; 8.08(2 \mathrm{H}, \mathrm{d}, 9.0) .{ }^{13} \mathrm{C}-\mathrm{NMR}\left(\mathrm{DMSO}-d_{6}\right)$ 8: $40.4(3)\left(\mathrm{CH}_{3}\right) ; 56.3\left(\mathrm{CH}_{3}\right) ; 56.4$ $\left(\mathrm{CH}_{3}\right) ; 113.6(\mathrm{CH}) ; 114.0(\mathrm{CH}) ; 117.8(\mathrm{CH}) ; 121.3(2)(\mathrm{CH}) ; 127.9(\mathrm{C}) ; 130.6(2)(\mathrm{CH}) ; 138.0(\mathrm{C}) ; 150.2(\mathrm{C})$; 150.8 (C); 153.1 (C); 194.1 (C). IR (KBr): 1662; 1600; 1496; 1413; 1226; $1035 \mathrm{~cm}^{-1}$. Mp (diethyl ether): 162-163 ${ }^{\circ} \mathrm{C}$. HRMS: calculated for $\mathrm{C}_{18} \mathrm{H}_{22} \mathrm{NO}_{3}[\mathrm{M}]^{+}$: 300.1594; found: 330.1600 .

4-((Hydroxyimino)(3,4,5-trimethoxyphenyl)methyl)-N,N,N-trimethylbenzenaminium iodide (6a). $100 \mathrm{mg}$ $(0.30 \mathrm{mmol})$ of oxime $\mathbf{2 a}$ and $0.200 \mathrm{~mL}$ ( $3.03 \mathrm{mmol})$ of iodomethane led to $31 \mathrm{mg}(0.09 \mathrm{mmol}, 30 \%)$ of $\mathbf{6 a}$, after crystallization in methanol/ethyl acetate. (Z): ${ }^{1} \mathrm{H}-\mathrm{NMR}\left(\mathrm{CD}_{3} \mathrm{OD}\right) \delta: 3.28(9 \mathrm{H}, \mathrm{s}) ; 3.73(6 \mathrm{H}, \mathrm{s}) ; 3.78$ $(3 \mathrm{H}, \mathrm{s}) ; 6.71(2 \mathrm{H}, \mathrm{s}) ; 7.62(2 \mathrm{H}, \mathrm{d}, 8.8) ; 8.01(2 \mathrm{H}, \mathrm{d}, 8.8)$. (E): ${ }^{1} \mathrm{H}-\mathrm{NMR}\left(\mathrm{CD}_{3} \mathrm{OD}\right) \delta: 3.30(9 \mathrm{H}, \mathrm{s}) ; 3.68(6 \mathrm{H}, \mathrm{s})$; $3.78(3 \mathrm{H}, \mathrm{s}) ; 6.60(2 \mathrm{H}, \mathrm{s}) ; 7.71(2 \mathrm{H}, \mathrm{d}, 8.8) ; 7.88(2 \mathrm{H}, \mathrm{d}, 8.8)$. IR (KBr): 3470; 1582; 1505; 1344; $1130 \mathrm{~cm}^{-1}$. $\mathrm{Mp}(\mathrm{EtOAc} / \mathrm{MeOH}): 179-180{ }^{\circ} \mathrm{C}$. HRMS: calculated for $\mathrm{C}_{19} \mathrm{H}_{25} \mathrm{~N}_{2} \mathrm{O}_{4}[\mathrm{M}]^{+}$: 345.1808; found: 345.1806.

N,N,N-trimethyl-4-(1-(3,4,5-trimethoxyphenyl)vinyl)benzenaminium iodide (7a). $250 \mathrm{mg}(0.83 \mathrm{mmol})$ of isocombretastatine $3 \mathbf{a}$ and $0.500 \mathrm{~mL}(7.97 \mathrm{mmol})$ of iodomethane led to $260 \mathrm{mg}(0.79 \mathrm{mmol}, 95 \%)$ of $7 \mathbf{a}$. ${ }^{1} \mathrm{H}-\mathrm{NMR}\left(\mathrm{CD}_{3} \mathrm{OD}\right)$ 8: $3.62(9 \mathrm{H}, \mathrm{s}) ; 3.68(6 \mathrm{H}, \mathrm{s}) ; 3.73(3 \mathrm{H}, \mathrm{s}) ; 5.59(1 \mathrm{H}, \mathrm{s}) ; 5.63(1 \mathrm{H}, \mathrm{s}) ; 6.53(2 \mathrm{H}, \mathrm{s}) ; 7.53$ $(2 \mathrm{H}, \mathrm{d}, 8.3) ; 7.93(2 \mathrm{H}, \mathrm{d}, 8.3) .{ }^{13} \mathrm{C}-\mathrm{NMR}\left(\mathrm{CD}_{3} \mathrm{OD}\right)$ 8: $56.7(3)\left(\mathrm{CH}_{3}\right) ; 57.8(2)\left(\mathrm{CH}_{3}\right) ; 61.1\left(\mathrm{CH}_{3}\right) ; 106.8(2)$ $(\mathrm{CH}) ; 116.9\left(\mathrm{CH}_{2}\right) ; 121.2(2)(\mathrm{CH}) ; 131.0(2)(\mathrm{CH}) ; 137.7$ (C); 144.8 (C); 145.9 (C); $147.7(\mathrm{C}) ; 149.5(\mathrm{C})$; 
154.4 (2) (C). IR (KBr): 1662; 1600; 1496; 1413; 1226; $1035 \mathrm{~cm}^{-1}$. Mp (acetone): 176-177 ${ }^{\circ} \mathrm{C}$. HRMS: calculated for $\mathrm{C}_{20} \mathrm{H}_{26} \mathrm{NO}_{3}[\mathrm{M}]^{+}$: 328.1907; found: 328.1899 .

$\mathrm{N}, \mathrm{N}, \mathrm{N}$-Trimethyl-4-(1-(2,3,4-trimethoxyphenyl)vinyl)benzenaminium iodide (7d). $170 \mathrm{mg}(0.54 \mathrm{mmol})$ of isocombretastatine $3 \mathbf{d}$ and $0.170 \mathrm{~mL}(2.71 \mathrm{mmol})$ of iodomethane led to $160 \mathrm{mg}(0.49 \mathrm{mmol}, 91 \%)$ of $\mathbf{7 d}$, after crystallization in methanol. ${ }^{1} \mathrm{H}-\mathrm{NMR}\left(\mathrm{DMSO}_{-} d_{6}\right) \delta: 3.35(3 \mathrm{H}, \mathrm{s}) ; 3.51(9 \mathrm{H}, \mathrm{s}) ; 3.66(3 \mathrm{H}, \mathrm{s}) ; 3.76$ $(3 \mathrm{H}, \mathrm{s}) ; 5.32(1 \mathrm{H}, \mathrm{s}) ; 5.70(1 \mathrm{H}, \mathrm{s}) ; 6.79(1 \mathrm{H}, \mathrm{d}, 8.2) ; 6.89(1 \mathrm{H}, \mathrm{d}, 8.2) ; 7.37(2 \mathrm{H}, \mathrm{d}, 8.6) ; 7.76(2 \mathrm{H}, \mathrm{d}, 8.6)$. ${ }^{13} \mathrm{C}-\mathrm{NMR}\left(\mathrm{DMSO}-d_{6}\right)$ 8: $55.9\left(\mathrm{CH}_{3}\right) ; 56.4(3)\left(\mathrm{CH}_{3}\right) ; 60.4(2)\left(\mathrm{CH}_{3}\right) ; 107.9(\mathrm{CH}) ; 117.7\left(\mathrm{CH}_{2}\right) ; 120.3(2)$ (CH); $124.8(\mathrm{CH}) ; 127.2$ (C); 127.4 (2) (CH); 141.8 (C); 142.6 (C); 144.6 (C); 146.1 (C); 150.9 (C); 153.6 (C). IR (KBr): $1594 ; 1496 ; 1459 ; 1406 ; 1295 ; 1090 \mathrm{~cm}^{-1}$. Mp (methanol): $168-169^{\circ} \mathrm{C}$. HRMS: calculated for $\mathrm{C}_{20} \mathrm{H}_{26} \mathrm{NO}_{3}[\mathrm{M}]^{+}$: 328.1907; found: 328.1913 .

N,N,N-trimethyl-4-(3,4,5-trimethoxystyryl)benzenaminium iodide (9a). $290 \mathrm{mg}(0.92 \mathrm{mmol})$ of a 1:1 Z/E mixture of combretastatine $8 \mathrm{a}$ and $0.500 \mathrm{~mL}$ ( $7.97 \mathrm{mmol})$ of iodomethane led to $260 \mathrm{mg}(0.79 \mathrm{mmol}, 86 \%)$ of a 7:3 Z/E mixture of compound 9a. After crystallization in acetone/ethyl acetate, $61 \mathrm{mg}(0.19 \mathrm{mmol}$, $21 \%)$ of isomer $Z$ were isolated. ${ }^{1} \mathrm{H}-\mathrm{NMR} \delta: 3.65(6 \mathrm{H}, \mathrm{s}) ; 3.79(3 \mathrm{H}, \mathrm{s}) ; 3.95(9 \mathrm{H}, \mathrm{s}) ; 6.37(2 \mathrm{H}, \mathrm{s}) ; 6.48(1 \mathrm{H}$, $\mathrm{d}, 12.2) ; 6.64(1 \mathrm{H}, \mathrm{d}, 12.2) ; 7.45(2 \mathrm{H}, \mathrm{d}, 8.6) ; 7.84(2 \mathrm{H}, \mathrm{d}, 8.6) .{ }^{13} \mathrm{C}-\mathrm{NMR} \delta: 56.2(2)\left(\mathrm{CH}_{3}\right) ; 57.9(3)\left(\mathrm{CH}_{3}\right) ;$ $60.9\left(\mathrm{CH}_{3}\right) ; 105.8(2)(\mathrm{CH}) ; 120.0(2)(\mathrm{CH}) ; 127.2(\mathrm{CH}) ; 131.0(2)(\mathrm{CH}) .132 .9(\mathrm{CH}) ; 138.4(\mathrm{C}) ; 139.6(\mathrm{C})$; 139.8 (C); 145.4 (C); 153.4 (2) (C). IR (KBr): 1581; 1240; 1125; $844 \mathrm{~cm}^{-1}$. Mp (acetone/ethylacetate): $75^{\circ} \mathrm{C}$. HRMS: calculated for $\mathrm{C}_{20} \mathrm{H}_{26} \mathrm{NO}_{3}[\mathrm{M}]^{+}$: 328.1907; found: 328.1916 .

N,N,N-trimethyl-5-(3,4,5-trimethoxystyryl)pyridin-2-aminium iodide (9b). $160 \mathrm{mg}(0.51 \mathrm{mmol})$ of a 1:1 Z/E mixture of combretastatin $\mathbf{8 b}$ and $0.320 \mathrm{~mL}(5.1 \mathrm{mmol})$ of iodomethane led to $213 \mathrm{mg}$ of reaction crude. After crystallization in acetone/methanol, $35 \mathrm{mg}(0.11 \mathrm{mmol}, 22 \%)$ of isomer $(\mathrm{Z})-9 \mathbf{b}$ were isolated. ${ }^{1} \mathrm{H}-\mathrm{NMR}\left(\mathrm{CD}_{3} \mathrm{OD}\right) \delta: 3.56(9 \mathrm{H}, \mathrm{s}) ; 3.75(3 \mathrm{H}, \mathrm{s}) ; 3.79(6 \mathrm{H}, \mathrm{s}) ; 6.84(2 \mathrm{H}, \mathrm{s}) ; 7.18(1 \mathrm{H}, \mathrm{d}, 1.0) ; 7.34(1 \mathrm{H}, \mathrm{d}$, 16.0); 7.79 (1H, d, 8.6); $8.17(1 \mathrm{H}, \mathrm{dd}, 8.6,2.2) ; 8.64(1 \mathrm{H}, \mathrm{d}, 2.2)$. IR (KBr): $1579 ; 1462 ; 1244 ; 1122 \mathrm{~cm}^{-1}$. HRMS: calculated for $\mathrm{C}_{19} \mathrm{H}_{25} \mathrm{~N}_{2} \mathrm{O}_{3}[\mathrm{M}]^{+}$: 329.1860; found: 329.1850 .

1-Methyl-1-(4-(3,4,5-trimethoxystyryl)phenyl)pyrrolidin-1-ium iodide (9i). $100 \mathrm{mg}(0.29 \mathrm{mmol})$ of combretastatin (Z)-8i and $0.182 \mathrm{~mL}(2.9 \mathrm{mmol})$ of iodomethane led to $92 \mathrm{mg}(0.26 \mathrm{mmol}, 89 \%)$ of isomer $(E)-9 \mathbf{i} .{ }^{1} \mathrm{H}-\mathrm{NMR}$

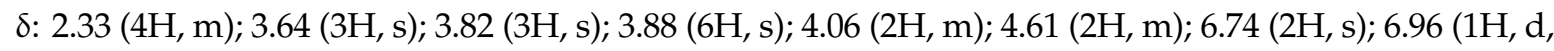
16.0); $7.05(1 \mathrm{H}, \mathrm{d}, 16.0) ; 7.61(2 \mathrm{H}, \mathrm{d}, 8.6) ; 7.84(2 \mathrm{H}, \mathrm{d}, 8.6) .{ }^{13} \mathrm{C}-\mathrm{NMR} \delta: 21.2(2)\left(\mathrm{CH}_{2}\right) ; 55.7\left(\mathrm{CH}_{3}\right) ; 56.4$ (2) $\left(\mathrm{CH}_{3}\right) ; 61.0\left(\mathrm{CH}_{3}\right) ; 66.7(2)\left(\mathrm{CH}_{2}\right) ; 104.0(2)(\mathrm{CH}) ; 121.6(2)(\mathrm{CH}) ; 125.3(\mathrm{CH}) ; 128.1(2)(\mathrm{CH}) ; 131.8(\mathrm{C})$; 132.1 (CH); 138.4 (C); 139.6 (C); 144.5 (C); 153.4 (2) (C). IR (KBr): 1583; 1247; 1125; $845 \mathrm{~cm}^{-1}$. Mp (acetone): 158-159 ${ }^{\circ} \mathrm{C}$. HRMS: calculated for $\mathrm{C}_{22} \mathrm{H}_{28} \mathrm{NO}_{3}[\mathrm{M}]^{+}: 354.2069$; found: 354.2044 .

\subsection{Aqueous Solubility Determination}

Compounds were stirred in a solution of phosphate buffer at $\mathrm{pH} 7.0$ (1-2 $\mathrm{mg}$ of compound in $300 \mu \mathrm{L}$ of buffer) during $48 \mathrm{~h}$. After that, the samples were filtered over a $45-\mu \mathrm{m}$ filter to discard the insoluble residues. In order to determine the maximum wavelength of absorbance for each compound, a scan between 270 and $400 \mathrm{~nm}$ was performed. Once the wavelength was selected, a calibration line was performed and the concentration of the stirred and filtered samples was measured.

\subsection{Cell Lines and Culture Conditions}

HeLa (human cervical carcinoma) and MCF-7 (human breast carcinoma) cell lines were cultured in Dulbecco's Modified Eagles Medium (DMEM) supplemented with 2 mM L-glutamine (Lonza-Cambrex, Karlskoga, Sweden), 10\% (v/v) heat inactivated fetal bovine serum (HIFBS) (Lonza-Cambrex) and $100 \mu \mathrm{g} / \mathrm{mL}$ streptomycin-100 IU/mL penicillin (Lonza-Cambrex) at $37^{\circ} \mathrm{C}$ in humidified $95 \%$ air and $5 \%$ $\mathrm{CO}_{2}$. HT-29 (human colon carcinoma) cells were cultured at $37^{\circ} \mathrm{C}$ in complete RPMI 1640 medium 
containing $2 \mathrm{mM}$ L-glutamine, 10\% (v/v) HIFBS and $100 \mu \mathrm{g} / \mathrm{mL}$ streptomycin-100 IU/mL penicillin in humidified $95 \%$ air and $5 \% \mathrm{CO}_{2}$ atmosphere.

\subsection{Cell Antiproliferative Assay}

The effect of the different compounds on the proliferation of human cell lines was determined by using the MTT (3-[4,5-dimethylthiazol-2-yl]-2,5-diphenyltetrazolium bromide) reagent (MTT Thiazolyl Blue Tetrazolium Bromide, Sigma-Aldrich, St. Louis, MO, USA) dissolved in PBS $5 \mathrm{mg} / \mathrm{mL}$. Cell viability was evaluated seeding $100 \mu \mathrm{L}$ of cells in exponential growth phase with appropriate cell line concentration $\left(1.5 \times 10^{4} \mathrm{HeLa}\right.$ and MCF-7 cells $/ \mathrm{mL}$ and $3 \times 10^{4} \mathrm{HT}-29$ cells $\left./ \mathrm{mL}\right)$ in complete medium in 96-well plates at $37^{\circ} \mathrm{C}$ and $5 \% \mathrm{CO}_{2}$. After $24 \mathrm{~h}$ incubation to allow cells to attach to the plates the ligands were added at different concentrations from $10^{-5}$ to $10^{-9} \mathrm{M}$. The effect on the proliferation was evaluated $72 \mathrm{~h}$ post-treatment by adding the MTT reagent $(10 \mu \mathrm{L} /$ well $)$ to a final concentration of $0.5 \mathrm{mg} / \mathrm{mL}$ and the plate was further incubated for another $3 \mathrm{~h}$. After this period, the supernatant was removed, the MTT violet crystals formed on the bottom of each well were dissolved in DMSO (100 $\mu \mathrm{L} /$ well) and subsequently, the absorbance of the color complex was read at $570 \mathrm{~nm}$ using a multi-well plate reader. Compounds were dissolved in dimethyl sulfoxide (DMSO) and the final solvent concentrations never exceeded $0.5 \%(v / v)$. The control wells included treated cells with $0.5 \%$ $(v / v)$ DMSO and the positive control. Measurements were performed in triplicate, and each experiment was repeated three times. The $\mathrm{IC}_{50}(50 \%$ inhibitory concentration with respect to the untreated controls) was determined for each compound. Nonlinear curves fitting the experimental data were carried out for each compound.

\subsection{Cell Cycle Analysis}

For the analysis of the cell cycle by flow cytometry, HeLa cells in exponential growth phase at $2 \times 10^{4}$ cells $/ \mathrm{mL}$ were seeded in 12-well plates $(1.5 \mathrm{~mL} /$ well). After $24 \mathrm{~h}$ incubation, cells were treated with approximately $5 \times \mathrm{IC}_{50}$ concentration of selected compounds and the effect was measured 24,48 and $72 \mathrm{~h}$ post-treatment. After the corresponding time, live and death cells were collected and fixed in ice-cold ethanol/PBS (7:3) overnight at $4{ }^{\circ} \mathrm{C}$. Cells were harvested by centrifugation, three times-washed in phosphate-buffered saline (PBS), treated with $0.05 \%$ RNase A and stained with propidium iodide in PBS overnight at room temperature. A total of 50,000 cells were analyzed using a BD Accuri ${ }^{\mathrm{TM}} \mathrm{C} 6$ flow cytometer and the $\mathrm{C} 6$ (version 1.0.264.21) software (BD Biosciences) to determine cell cycle distribution and compared to control cells.

\subsection{Apoptotic Cell Death Assay}

Apoptotic cells were quantified using an Annexin V-FITC/PI apoptosis detection kit (Immunostep, Salamanca, Spain). $1.5 \mathrm{~mL} /$ well of HeLa cells were seeded onto 12-well plates at a density of $2 \times 10^{4}$ cells $/ \mathrm{mL}$ and left to attach overnight. After $24 \mathrm{~h}$ cells were treated at approximately $5 \times \mathrm{IC}_{50}$ concentration. After $72 \mathrm{~h}$ and 6 days post-treatment, attached and floating cells were collected, centrifugated, resuspended in the Annexin V binding buffer and stained with Annexin V-FITC/PI according to the manufacturer's procedure. It was incubated at room temperature for $15 \mathrm{~min}$ and a total of 30,000 cells were acquired using the BD Accuri ${ }^{\mathrm{TM}} \mathrm{C} 6$ flow cytometer (BD Biosciences) as previously described.

\subsection{Tubulin Isolation}

Bovine brain microtubule protein (MTP) was isolated as previously described [23]. Briefly, it was purified according to the modified Shelanski method by two cycles of temperature-dependent assembly/disassembly [33]. 


\subsection{Tubulin Polymerization Inhibition Assay}

Tubulin polymerization was monitored using a Helios $\alpha$ spectrophotometer by measuring the increase in turbidity at $450 \mathrm{~nm}$, caused by a shift from $4{ }^{\circ} \mathrm{C}$ to $37^{\circ} \mathrm{C}$, which allows the in vitro MTP self-disassembly and assembly respectively. Compounds, solved in DMSO, were prepared at the appropriate concentration in 0.1 M MES buffer, $1 \mathrm{mM}$ ethylene glycol-bis(2-aminoethyl)- $N, N, N^{\prime}, N^{\prime}$-tetraacetic acid (EGTA), $1 \mathrm{mM}$ $\mathrm{MgCl}_{2}, 1 \mathrm{mM} \beta-\mathrm{ME}$, and $1.5 \mathrm{mM}$ GTP at pH 6.7 (never exceeding 4\% DMSO, which has been reported not to interfere with the assembly process). Firstly, ligands at $20 \mu \mathrm{M}$ concentration, were incubated with $1.5 \mathrm{mg} / \mathrm{mL} \mathrm{MTP}$ at $20{ }^{\circ} \mathrm{C}$ for $30 \mathrm{~min}$ and subsequently cooled on ice for $10 \mathrm{~min}$. Then, the experiment starts at $4{ }^{\circ} \mathrm{C}$ to establish the initial baseline. The assembly process was initiated by shifting of the temperature to $37^{\circ} \mathrm{C}$ and the turbidity produced can be measured by an absorbance increase. After reaching a stable plateau, the temperature was switched back to $4{ }^{\circ} \mathrm{C}$ to return to the initial absorption values. The difference in amplitude between the stable plateau and the initial baseline of the curves was taken as the degree of tubulin polymerization for each experiment. Comparison with control curves under identical conditions but without ligands yielded tubulin polymerization inhibition as a percentage value. Finally, the $\mathrm{IC}_{50}$ was calculated for compounds that inhibit tubulin polymerization more than $50 \%$ at $20 \mu \mathrm{M}$. All the measurements were carried out in at least two independent experiments using MTP from different isolation.

\subsection{Effect on Rat Primary Pancreatic Cells}

Rat primary pancreatic cells were isolated as previously described [18]. Afterwards, pancreatic cells were resuspended in Na-HEPES solution ( $\mathrm{pH} 7.4$ ) containing $14 \mathrm{mM}$ glucose, $1 \%$ essential amino acid mixture, $1 \%(w / v)$ BSA, $0.01 \%(w / v)$ STI, $0.5 \mathrm{mM} \mathrm{CaCl} 2$ and incubated $\left(5 \% \mathrm{CO}_{2}\right.$, at $\left.37^{\circ} \mathrm{C}\right)$ for $7 \mathrm{~h}$ in the absence (non-treated control) or the presence of compounds at different concentrations. After the treatment, cells were incubated $\left(5 \% \mathrm{CO}_{2}\right.$, at $\left.37^{\circ} \mathrm{C}\right)$ with $0.5 \mathrm{mg} / \mathrm{mL} \mathrm{MTT}$ for $2 \mathrm{~h}$ and the formazan crystals were solubilized with DMSO $(v / v)$. The optical density was read at $570 \mathrm{~nm}$ with a reference wavelength of $630 \mathrm{~nm}$. Non-treated cell viability was set as $100 \%$.

\subsection{Molecular Modelling}

The binding mode of compounds 1-9 at the colchicine site of tubulin was studied by docking experiments. The virtual ligands were built with Marvin [34]. When different isomers were possible, i.e., $Z$ - and $E$ - oximes (2 and 6) or $R$ - and $S$ - 1,1-diarylethanes (4) they were independently studied. The flexibility of the colchicine site was simulated by employing multiple configurations represented by the structures of 50 complexes of tubulin with different colchicine site ligands available at the Protein Data Bank (pdb) [35]. The protein structures were superimposed and prepared for docking with Swiss-Model [36], Chimera [37], and AutoDock Tools [38] and docking was performed with three programs employing different scoring functions: DOCK6.9 [32], PLANTS [31] and AutoDock 4.2 [38]. The docking results were semi-automatically processed by means of home-made scripts and KNIME [39] workflows that classify the binding poses according to the colchicine subsites they occupy and the combined binding energies of the three programs. The results were analyzed with AutoDockTools [38], Marvin [34], OpenEye [40], and JADOPPT [41]. Docking poses were selected if they were found by at least two docking programs using different scoring functions and based on the scoring. The selected binding mode for each ligand were those with better conjoint scoring. In order to validate the docking protocol, reference ligands with known binding modes at the colchicine site were docked using the same protocol and shown to produce the correct binding modes.

\section{Conclusions}

A new strategy for increasing molecular polarity without exposing polar groups termed masked polar group incorporation (MPGI) has been proposed as a means to increase the aqueous solubility of ligands binding at hydrophobic pockets. We applied MPGI to combretastatin analogues and designed 
pyridine analogues with vicinal nitrogenated substituents acting as the masking groups and synthesized a new family of compounds with a 3- or 4-pyridine ring replacing the 3-hydroxy-4-methoxyphenyl (B) ring of combretastatin A4, in an attempt to increase the aqueous solubility and remove the 3-hydroxyl group causing resistance by glucuronidation. The resulting analogues showed improved aqueous solubilities and highly potent antiproliferative activity against several cancer cell lines of different origin. The new compounds showed tubulin polymerization inhibitory activity, cell cycle arrest at the $\mathrm{G}_{2} / \mathrm{M}$ phase and subsequent apoptotic cell death. Docking studies suggest binding at the colchicine site of tubulin in a similar way as combretastatin A4 with the polar groups masked by the vicinal substituents. These results validate the proposed strategy for the design of colchicine site ligands and open a new road to increasing the aqueous solubility of ligands binding in apolar environments.

Supplementary Materials: The following are available online: Table S1: the details of the docking results.

Author Contributions: Conceptualization, R.P., E.C. and M.M.; methodology, M.G., Y.E., A.V.-B., L.R., R.Á., R.P., M.M., C.S., L.G.-Y.; software, R.P.; validation, R.P., M.M., E.C., R.Á.; formal analysis, R.P., M.M., E.C., R.Á.; investigation, L.G.-Y., Y.E., M.G., A.V.-B., L.R., M.M.F., R.Á., R.P.; resources, M.M., R.P.; data curation, M.G., R.Á., E.C., M.M., R.P.; writing—original draft preparation, Y.E, E.C., R.P., R.Á., L.G.-Y.; writing—review and editing, R.P.; visualization, R.P.; supervision, R.P., E.C, M.M., R.Á.; project administration, R.P., M.M.; funding acquisition, R.P., M.M.

Funding: This research was funded by Consejería de Educación de la Junta de Castilla y León and FEDER Funds (SA030U16 and SA262P18) and Ministerio de Ciencia, Innovación y Universidades, Proyectos I + D + i «Retos de Investigación» del Programa Estatal de I + D + i Orientada a los Retos de la Sociedad RTI2018-099474-B-I00.

Acknowledgments: M.G. acknowledges a predoctoral fellowship from the Consejería de Educación de la Junta de Castilla y León (EDU/602/2016). Y.E. acknowledges a predoctoral fellowship from the AECID. A.V.B. acknowledges a predoctoral fellowship from the Ministerio de Educación, Cultura y Deporte (FPU15/02457). We acknowledge the NMR and MS facilities of the Nucleus Platform of the University of Salamanca for the spectra.

Conflicts of Interest: The authors declare no conflicts of interest. The funders had no role in the design of the study; in the collection, analyses, or interpretation of data; in the writing of the manuscript, or in the decision to publish the results.

\section{References}

1. Dumontet, C.; Jordan, M.A. Microtubule-binding agents: A dynamic field of cancer therapeutics. Nat. Rev. Drug Discov. 2010, 9, 790-803. [CrossRef] [PubMed]

2. Bates, D.; Eastman, A. Microtubule destabilising agents: Far more than just antimitotic anticancer drugs. Br. J. Clin. Pharmacol. 2017, 83, 255-268. [CrossRef] [PubMed]

3. Perez-Perez, M.J.; Priego, E.M.; Bueno, O.; Martins, M.S.; Canela, M.D.; Liekens, S. Blocking blood flow to solid tumors by destabilizing tubulin: An approach to targeting tumor growth. J. Med. Chem. 2016, 59, 8685-8711. [CrossRef] [PubMed]

4. Tron, G.C.; Pirali, T.; Sorba, G.; Pagliai, F.; Busacca, S.; Genazzani, A.A. Medicinal chemistry of combretastatin A4: Present and future directions. J. Med. Chem. 2006, 49, 3033-3044. [CrossRef]

5. Seddigi, Z.S.; Malik, M.S.; Saraswati, A.P.; Ahmed, S.A.; Babalghith, A.O.; Lamfon, H.A.; Kamal, A. Recent advances in combretastatin based derivatives and prodrugs as antimitotic agents. MedChemComm 2017, 8 , 1592-1603. [CrossRef]

6. Messaoudi, S.; Treguier, B.; Hamze, A.; Provot, O.; Peyrat, J.F.; De Losada, J.R.; Liu, J.M.; Bignon, J.; Wdzieczak-Bakala, J.; Thoret, S.; et al. Isocombretastatins a versus combretastatins a: The forgotten isoCA-4 isomer as a highly promising cytotoxic and antitubulin agent. J. Med. Chem. 2009, 52, 4538-4542. [CrossRef]

7. Alvarez, R.; Alvarez, C.; Mollinedo, F.; Sierra, B.G.; Medarde, M.; Pelaez, R. Isocombretastatins A: 1,1-Diarylethenes as potent inhibitors of tubulin polymerization and cytotoxic compounds. Bioorg. Med. Chem. 2009, 17, 6422-6431. [CrossRef]

8. Pettit, G.R.; Toki, B.; Herald, D.L.; Verdier-Pinard, P.; Boyd, M.R.; Hamel, E.; Pettit, R.K. Antineoplastic agents. 379. Synthesis of phenstatin phosphate. J. Med. Chem. 1998, 41, 1688-1695. [CrossRef]

9. Aprile, S.; Del Grosso, E.; Grosa, G. Identification of the human UDP-glucuronosyltransferases involved in the glucuronidation of combretastatin A-4. Drug Metab. Dispos. Biol. Fate Chem. 2010, 38, 1141-1146. [CrossRef] 
10. Alvarez, R.; Puebla, P.; Diaz, J.F.; Bento, A.C.; Garcia-Navas, R.; de la Iglesia-Vicente, J.; Mollinedo, F.; Andreu, J.M.; Medarde, M.; Pelaez, R. Endowing indole-based tubulin inhibitors with an anchor for derivatization: Highly potent 3-substituted indolephenstatins and indoleisocombretastatins. J. Med. Chem. 2013, 56, 2813-2827. [CrossRef]

11. Alvarez, C.; Alvarez, R.; Corchete, P.; Lopez, J.L.; Perez-Melero, C.; Pelaez, R.; Medarde, M. Diarylmethyloxime and hydrazone derivatives with 5 -indolyl moieties as potent inhibitors of tubulin polymerization. Bioorg. Med. Chem. 2008, 16, 5952-5961. [CrossRef]

12. Liou, J.-P.; Wu, C.-Y.; Hsieh, H.-P.; Chang, C.-Y.; Chen, C.-M.; Kuo, C.-C.; Chang, J.-Y. 4- and 5-Aroylindoles as novel classes of potent antitubulin agents. J. Med. Chem. 2007, 50, 4548-4552. [CrossRef]

13. Maya, A.B.S.; Perez-Melero, C.; Mateo, C.; Alonso, D.; Fernandez, J.L.; Gajate, C.; Mollinedo, F.; Pelaez, R.; Caballero, E.; Medarde, M. Further naphthylcombretastatins. An investigation on the role of the naphthalene moiety. J. Med. Chem. 2005, 48, 556-568. [CrossRef]

14. Wang, L.; Woods, K.W.; Li, Q.; Barr, K.J.; McCroskey, R.W.; Hannick, S.M.; Gherke, L.; Credo, R.B.; Hui, Y.-H.; Marsh, K.; et al. Potent, orally active heterocycle-based combretastatin a-4 analogues: Synthesis, structure-activity relationship, pharmacokinetics, and in vivo antitumor activity evaluation. J. Med. Chem. 2002, 45, 1697-1711. [CrossRef]

15. Cushman, M.; Nagarathnam, D.; Gopal, D.; Chakraborti, A.K.; Lin, C.M.; Hamel, E. Synthesis and evaluation of stilbene and dihydrostilbene derivatives as potential anticancer agents that inhibit tubulin polymerization. J. Med. Chem. 1991, 34, 2579-2588. [CrossRef]

16. Jimenez, C.; Ellahioui, Y.; Alvarez, R.; Aramburu, L.; Riesco, A.; Gonzalez, M.; Vicente, A.; Dahdouh, A.; Ibn Mansour, A.; Jimenez, C.; et al. Exploring the size adaptability of the B ring binding zone of the colchicine site of tubulin with para-nitrogen substituted isocombretastatins. Eur. J. Med. Chem. 2015, 100, 210-222. [CrossRef]

17. Caron, G.; Kihlberg, J.; Ermondi, G. Intramolecular hydrogen bonding: An opportunity for improved design in medicinal chemistry. Med. Res. Rev. 2019, 39, 1707-1729. [CrossRef]

18. Mateu, A.; Ramudo, L.; Manso, M.A.; Closa, D.; De Dios, I. Acinar inflammatory response to lipid derivatives generated in necrotic fat during acute pancreatitis. Biochim. Et Biophys. Acta 2014, 1842, 1879-1886. [CrossRef]

19. Ahmad, N.M. Solubility-driven lead optimisation: Recent examples and personal perspectives. Bioorg. Med. Chem. Lett. 2016, 26, 2975-2979. [CrossRef]

20. Vicente-Blazquez, A.; Gonzalez, M.; Alvarez, R.; Del Mazo, S.; Medarde, M.; Pelaez, R. Antitubulin sulfonamides: The successful combination of an established drug class and a multifaceted target. Med. Res. Rev. 2019, 39, 775-830. [CrossRef]

21. Alvarez, R.; Medarde, M.; Pelaez, R. New ligands of the tubulin colchicine site based on X-ray structures. Curr. Top. Med. Chem. 2014, 14, 2231-2252. [CrossRef]

22. Gwaltney, S.L.; Imade, H.M.; Barr, K.J.; Li, Q.; Gehrke, L.; Credo, R.B.; Warner, R.B.; Lee, J.Y.; Kovar, P.; Wang, J.; et al. Novel sulfonate analogues of combretastatin A-4: Potent antimitotic agents. Bioorg. Med. Chem. Lett. 2001, 11, 871-874. [CrossRef]

23. Alvarez, R.; Gajate, C.; Puebla, P.; Mollinedo, F.; Medarde, M.; Pelaez, R. Substitution at the indole 3 position yields highly potent indole combretastatins against human tumor cells. Eur. J. Med. Chem. 2018, 158, 167-183. [CrossRef]

24. Xu, F.; Li, W.; Shuai, W.; Yang, L.; Bi, Y.; Ma, C.; Yao, H.; Xu, S.; Zhu, Z.; Xu, J. Design, synthesis and biological evaluation of pyridine-chalcone derivatives as novel microtubule-destabilizing agents. Eur. J. Med. Chem. 2019, 173, 1-14. [CrossRef]

25. Alvarez, R.; Aramburu, L.; Puebla, P.; Caballero, E.; Gonzalez, M.; Vicente, A.; Medarde, M.; Pelaez, R. Pyridine based antitumour compounds acting at the colchicine site. Curr. Med. Chem. 2016, 23, 1100-1130. [CrossRef]

26. Soussi, M.A.; Provot, O.; Bernadat, G.; Bignon, J.; Desravines, D.; Dubois, J.; Brion, J.-D.; Messaoudi, S.; Alami, M. IsoCombretaQuinazolines: Potent cytotoxic agents with antitubulin activity. ChemMedChem 2015, 10, 1392-1402. [CrossRef]

27. Messaoudi, S.; Hamze, A.; Provot, O.; Treguier, B.; Rodrigo De Losada, J.; Bignon, J.; Liu, J.-M.; Wdzieczak-Bakala, J.; Thoret, S.; Dubois, J.; et al. Discovery of isoerianin analogues as promising anticancer agents. ChemMedChem 2011, 6, 488-497. [CrossRef]

28. Ishikawa, M.; Hashimoto, Y. Improvement in aqueous solubility in small molecule drug discovery programs by disruption of molecular planarity and symmetry. J. Med. Chem. 2011, 54, 1539-1554. [CrossRef] 
29. Gaillard, T. Evaluation of autodock and autodock vina on the CASF-2013 Benchmark. J. Chem. Inf. Model. 2018, 58, 1697-1706. [CrossRef]

30. Korb, O.; Stutzle, T.; Exner, T.E. Empirical scoring functions for advanced protein-ligand docking with PLANTS. J. Chem. Inf. Model. 2009, 49, 84-96. [CrossRef]

31. Goodsell, D.S.; Morris, G.M.; Olson, A.J. Automated docking of flexible ligands: Applications of autodock. J. Mol. Recognit. JMR 1996, 9, 1-5. [CrossRef]

32. Allen, W.J.; Balius, T.E.; Mukherjee, S.; Brozell, S.R.; Moustakas, D.T.; Lang, P.T.; Case, D.A.; Kuntz, I.D.; Rizzo, R.C. DOCK 6: Impact of new features and current docking performance. J. Comput. Chem. 2015, 36, 1132-1156. [CrossRef]

33. Shelanski, M.L.; Gaskin, F.; Cantor, C.R. Microtubule assembly in the absence of added nucleotides. Proc. Natl. Acad. Sci. USA 1973, 70, 765-768. [CrossRef]

34. ChemAxon Marvin 17.8. Available online: http://www.chemaxon.com (accessed on 11 January 2017).

35. Goodsell, D.S.; Zardecki, C.; Di Costanzo, L.; Duarte, J.M.; Hudson, B.P.; Persikova, I.; Segura, J.; Shao, C.; Voigt, M.; Westbrook, J.D.; et al. RCSB protein data bank: Enabling biomedical research and drug discovery. Protein Sci. Publ. Protein Soc. 2019. [CrossRef]

36. Guex, N.; Peitsch, M.C. SWISS-MODEL and the Swiss-PdbViewer: An environment for comparative protein modeling. Electrophoresis 1997, 18, 2714-2723. [CrossRef]

37. Pettersen, E.F.; Goddard, T.D.; Huang, C.C.; Couch, G.S.; Greenblatt, D.M.; Meng, E.C.; Ferrin, T.E. UCSF Chimera-A visualization system for exploratory research and analysis. J. Comput. Chem. 2004, 25, 1605-1612. [CrossRef]

38. Forli, S.; Huey, R.; Pique, M.E.; Sanner, M.F.; Goodsell, D.S.; Olson, A.J. Computational protein-ligand docking and virtual drug screening with the AutoDock suite. Nat. Protoc. 2016, 11, 905-919. [CrossRef]

39. Berthold, M.R.; Cebron, N.; Dill, F.; Gabriel, T.R.; Kötter, T.; Meinl, T.; Ohl, P.; Sieb, C.; Thiel, K.; Wiswedel, B. KNIME: The Konstanz Information Miner. In Studies in Classification, Data Analysis, and Knowledge Organization. Springer: Berlin, Germany, 2007; pp. 319-326.

40. OpenEye Solution. Available online: https://www.eyesopen.com/ (accessed on 3 January 2017).

41. Garcia-Perez, C.; Pelaez, R.; Theron, R.; Luis Lopez-Perez, J. JADOPPT: Java based AutoDock preparing and processing tool. Bioinformatics 2017, 33, 583-585. [CrossRef]

Sample Availability: Samples of the compounds 1-9 are available from the authors.

(C) 2019 by the authors. Licensee MDPI, Basel, Switzerland. This article is an open access article distributed under the terms and conditions of the Creative Commons Attribution (CC BY) license (http://creativecommons.org/licenses/by/4.0/). 